
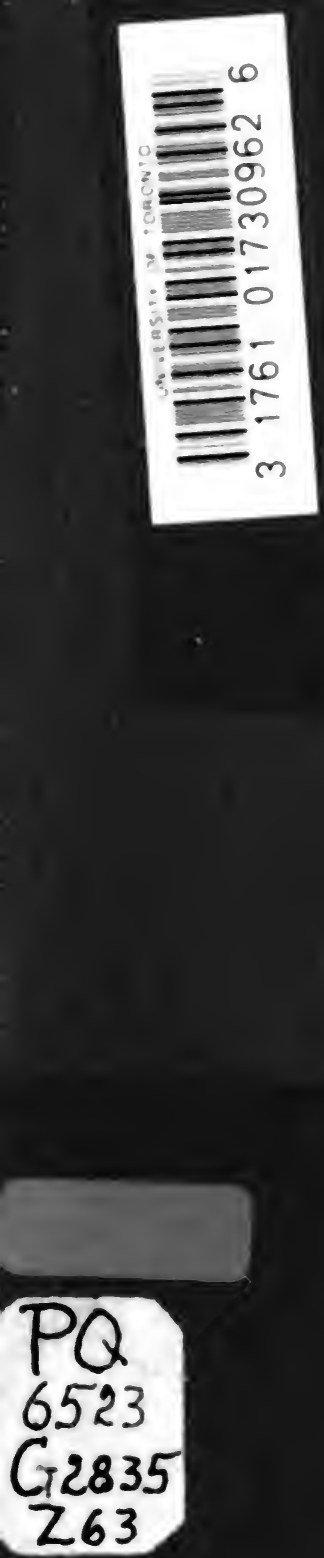


\section{Digitized by the Internet Archive in 2007 with funding from Microsoft Corporation}






\title{
The Romantic Dramas
}

\author{
of \\ García Gutiérre'
}

\section{Wyitre}




\section{The Institute of International Education INSTITUTO DE LAS ESPANAS EN LOS ESTADOS UNIDOS \\ 419 West 117 th Street, New York City}

\section{PUBLICACIONES}

Lo que se puede aprender en España, por Joaquín Ortega, University of Wisconsin $\$ 0.15$

Cervantes. - Cartilla escolar - Biografia y Selección por M. Romea-Navarro, University of Pennsylvania, Vocabulario por Julio Mercado, Commercial High School, Brooklyn

La enseñanza de lenguas modernas en los Estados Unidos, por Lawrence A. Wilkins, Director of Modern Languages, New York City

The Romantic Dramas of García Gutiérrez, by Nicholson B. Adams, $\mathrm{Ph}$. D., Instructor in Teachers College, Columbia University.

Memoria del Curso 1920-1921 (edición en inglés y en español)

Centro de Estudios históricos. - Courses in Spanish Language and Literature for foreigners. Madrid, 1922. 11th year. 


\section{The Romantic Dramas \\ of Garcia Gutierrez}

NICHOLSON B. ADAMS, Ph. D.

Instructor in French and Spanish. Teachers College.

Columbia University.

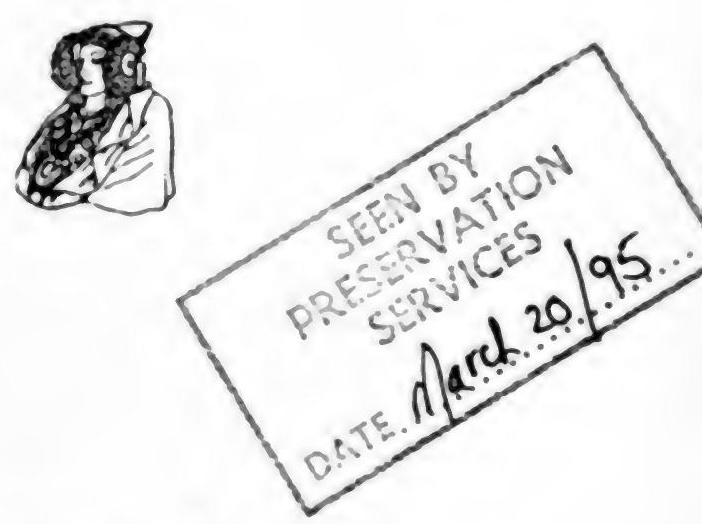

\section{INSTITUTO DE YNESPANAS




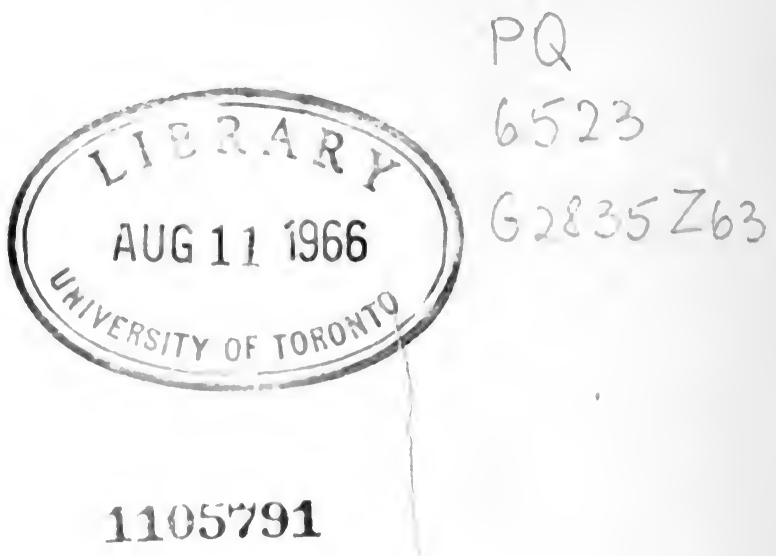

\author{
Es propiedad. \\ Derechos reservados \\ para todos los paises. \\ Copyright, 1922, \\ by the Instituto de las Españas
}

Carranze \& Co., Inc., impresores, New York. 


\section{PREFACE}

Since the number of special works devoted to the Romantic movement in Spain is not large, and since, as far as the author has been able to ascertain, there is no work in English dealing particularly uith Garcia Gutierrez, it is hoped that this modest treatise may be of service to those interested in Spanish Romanticism and perhaps to students of Spanish literature in gen. eral. The author's ou'n interest in this period is keen, and he hopes to do further work upon Garcia Gutikrrez and his contemporaries. If by the publication of this work he can in any way aid others with similar interests, he will be more than satisfied.

The first chapter of this book does not claim to be a complete biography gleaned from original sources; it is given for the conzenience of those who might wish to refresh their memories upon the already known facts of the life of Garcia Gutierrez.

The author wishes to acknowledge with many thanks his indebtedness to Professor Federico de Onis, of Columbia University, for constant aid and most helpful criticism; to Professor John L. Gerig, Columbia, and Henri Chamard, Visiting Professor at Columbia, for very zaluable suggestions; and to Professor Henry Alfred Todd of Columbia for his most kindly encouragement and aid at every stage of this work, including the correction of the proofs.

$$
\text { N.B. A. }
$$

Columbia University,

April, 1922. 



\title{
THE ROMANTIC DRAMAS OF GARCIA GUTIERREZ
}

\author{
CHAPTER I.
}

Blographical. SKetch.

Antonio Garcia Gutierrez was born in the village of Chiclana, near Cadiz, on July 5, 1813.' His father, a poor artisan, was ambitious for his son, and gave him the best schooling possible. The report of one of his first teachers, a certain Sr. Galante, must have been very discouraging to the anxious parents, for he assured them that their boy Antonio would never learn to read, much less to write. Nevertheless he passed successfully through the elementary schools, and matriculated under the Faculty of Medicine in the University of Cadiz. The study of medicine, however, had no attractions for him, and the closing of the universities by an ominous decree of Ferdinand VII must have come as a great relief to him. Throughout his school career he had had the habit of scribbling verses instead of studying,

s For the sources of thla blography, see Obras escogidas de Don Antowio Gareia Gutierrez, Madrid, 1866, Dp. v-xxil and Awtores dremdticos contempord weos, by Novo y Colson, Madrid. 1881. vol. I. np. 81-96. 


\section{Biographical Sketch}

a habit which his father found highly reprehensible and took stern measures to repress. Antonio, however, not to be thwarted, conceived the idea of taking advantage of his father's near-sightedness, and began to write in characters so fine that his productions escaped parental notice - but at the same time almost ruined his own eyesight. His eyes continued to give him trouble all his life.

By the time he was twenty, the young man's fondness for writing had developed into a real passion, and he resolved forthwith to break into the world of letters. Chafing under his father's disapproval and hindrance, and impatient to begin his chosen career, he formed the desperate plan of going to Madrid. A friend agreed to share his enterprise. Garcia Gutiérrez's literary baggage at the time consisted of two comedies, Una noche de baile, and Peor es urgallo, and two tragedies, Selim, hijo de Bayaceto and Fingal. The two friends set out on foot August 16, 1833 and after spending seventeen days on the road reached Madrid September 2.

The foremost theatrical producer at the time in Madrid was the Frenchman Juan Grimaldi. He had been highly successful in his play Todo lo vence amor, better known by its sub-title La pata de cabra. It is described on its title-page as a "melomimo-drama mitológico-burlesco de magia y de grande espectáculo," and fully justifies its description. Grimaldi was now manager of the two oldest theaters in Madrid, the Teatro de la Cruz (founded 1579) 
and the Teatro del Principe (1582). His best actress was Concepción Rodriguez, who was also his wife. It was to Grimaldi, then, that Garcia Gutiérrez had recourse. The comedy Una noche de baile had been read at the Cafe del Principe by Larra, Espronceda and Ventura de la Vega, and had been viewed with favor by them. Although Grimaldi did not produce the play, he must have been favorably impressed with the author, for he was instrumental in securing for him a modest position on the editorial staff of the Revista Española.

While this Review gave the aspiring dramatist an opportunity to see the plays then being presented in Madrid and enabled him to make a scant living, he soon saw that fame and fortune were not to be attained by his contributions to its columns. Moreover his predilection was for the drama. Since his original plays had not been considered worthy of production, he tried his hand at translation. His first effort, a Spanish version of Scribe's Le Vampire, was played in Madrid in October, 1834. The original had been put on in Paris at the Theatre du Vaudeville in 1820 . The next year, 1835, saw the presentation of two more translations from Scribe. The first bore the tile of Batilde, from the name of the heroine of La Bohemienne, ou l'Aamérique en 1775, presented at the Theatre du Gymnase in 1829. Le Quaker et la Danseuse, shown at the same theatre in 1831, bore in Spanish the title El cudkero y la 
cómica. This play, and also El vampiro, had only one act. Batilde had five.

It was during these years that Romanticism became definitely established in Spain. Larra's Macias was played in 1834, and the Don Alvaro of the Duke of Rivas and the Aljredo of Pacheco in the following year. The influence of these plays upon García Gutiérrez was marked and immediate. He resolved to try something of this new kind, which had been so successful. The actual writing of $E l$ trovador, according to Cayetano Rosell (Autores dramáticos contemporáneos, p. 85) required only five months. It was offered to Grimaldi, who accepted it for presentation in the Teatro de la Cruz. The company at this theatre was inferior to that at the Teatro del Príncipe, but the young author hardly felt himself in a position to protest against this decision. Worse luck than this was in store for him, for the "apuntador" to whose lot it fell to read the parts to the actors was entirely out of sympathy with his Romantic imaginings and performed his task with such ill grace that he convinced the actors the presentation of the play was impossible. One of these, however, Lombia by name, predicted that the drama would be brilliantly successful, if well acted and staged. This must have been small comfort for the young author, whose many disappointments now convinced him that a literary career was not the one for him; and he resolved to abandon it definitely and to seek his 
fortune in other fields. He was desperate and ready to take up with the first opportunity that offered of gaining a livelihood.

Many a Spanish man of letters had wielded the sword as well as the pen. At this moment of com. plete discouragement of his youthful hopes, Garcia Gutierrez probably had little thought of the example of the illustrious company of writers headed by Cervantes, but all the same it was the army that now claimed him as its own. The Carlist war was going merrily on at this time, and the Minister Mendizábal hoped to put an end to it by raising a levy of one hundred thousand troops. To make recruiting brisker, he offered a Second Lieutenant's commission to all volunteers serving six months who had had as much as two years' schooling beyond the elementary grades. Garcia Gutiérrez enlisted, and was sent to the recruiting depot in the nearby village of Leganés. He had been there but a short time when he received news that must have upset him, as well as delighted him. Espronceda, it transpired, had read El trovador with enthusiasm, and had expressed his astonishment that so excellent a play had been indefinitely hung up. He was influential enough with Grimaldi to secure another trial for El trovador, and it was put in rehearsal. The comedian Guzmán had accepted it for his benefit performance - a strange selection surely for a comedian, but he was probably better suited for this play than the actors accustomed to the pseudo- 
classic tragedies then holding the boards. The first of March, 1836, was the day set for the première. Word was spread that something new and daring was to be presented, and the interest of the theatregoing public was thoroughly aroused. Mendizábal's new recruit unconscionably forgot his military duties and made his way to Madrid - absent without leave from his company at Leganés.

Ferrer del Río, who was present at the first performance, has given us a graphic description of it (Galería de la literatura española; quoted by Hartzenbusch, in his Obras escogidas de Garcia Gutierrez, and also by Regensburger; see bibliography). His account of the occasion reads as follows:

The night of the 1st of March, 1836, came, and not one of the seats in the Teatro del Principe was vacant. People kept asking one another who was the author of the knightly drama on the bill, and no one knew him. When the curtain rose, you might have observed a movement of curiosity in all the spectators; next, profound attention; after a few scenes they were showing their approval, and at the end of the first act all were applauding. Their interest increased during the acts which followed, and their admiration was doubled upon observing the careful structure of the plot, the novelty of its peripeteias; the unexpectedness of its situations, and the richness of its poetry. Not a single scene was considered tedious, there was not a single inharmonious phrase and not a single idea amiss. When the curtain fell, the same honors were achieved by this drama as by others; but the ecstatic hand-clapping was succeeded 
by a new spectacle, a distinction never conferred until then on our stage; the audience demanded the appearance of the author before the curtain, and with such insistence that none would stir from his seat until the wish was granted. Don Carlos Latorre and Doña Concepción Rodriguez escorted Garcia Gutiérrez forward, visibly affected by seeing himself the object of such distinguished homage. He was in such destitute circumstances that, in order to appear before the audience in decent attire, he had to borrow a militiaman's coat from a friend (Don Ventura de la Vega), who made him this hasty loan behind the scenes.

The next day Madrid talked of nothing but the knightly drama; from an early hour on, the box office was besieged by serving-men and ticketbrokers; even the most careful fathers of families promised their children a visit to the theatre, as if it had been a comedy of magic; the first edition of $\boldsymbol{E l}$ trovador was sold in two weeks. Its mellifluous verses ran from mouth to mouth; it was performed for many evenings, and the author was granted a benefit performance. Mendizábal gave him a full discharge from the army.

After this decisive success, Garcia Gutiérrez gratified a filial wish by returning home and describing his triumph to his parents - a return far different from that of a Prodigal Son. In the South he remained for four months, utilizing his leisure there by beginning the composition of another play of the same general style but of less inspiration. This was El paje, produced on May 22, 1837. Its reception seems to have implied somewhat of a succès 
d'estime; Cayetano Rosell tells us that the public, while admiring the beauty of its verse, objected to what it considered the immorality of its plot.

In this same year Garcia Gutiérrez produced three other plays. The first was El sitio de Bilbao. The edition published by Yenés, Madrid, 1837, bears no author's name, but simply the title and the description "drama de circunstancias en dos actos en prosa y verso." Both Hartzenbusch and Cayetano Rosell $^{2}$ state that it is the work of Garcia Gutiérrez in collaboration with Isidoro Gil. The other two plays of this year were Magdalena and La Pandilla, the latter being a translation from Scribe. Approximately the same rate of production was continued for several years. The period from 1838 to 1842 saw the publication and presentation of fifteen plays, of which eight were original and seven were translations from the French. Margarita de Borgoña, a translation of Alexander Dumas' La Tour de Nesle, appeared in 1840 .

The next great dramatic success achieved by García Gutiérrez came in the year 1843 with Simón Bocanegra, which was shown on January 17 at the Teatro de la Cruz. Cayetano Rosell states (Autores dramáticos contemporáneos, p. 90) that our author abandoned the stage from the year 1840 to 1843 , but the existence of four plays produced within those dates furnishes proof to the contrary. These plays

2 In volumes mentioned in note 1. 
are El caballero leal, Zaida, Juan de Swavia and $E \boldsymbol{L}$ premio del vencedor. But these were very mild successes as compared with Simón Bocanegra. In the case of this last the enthusiasm of the firstnight audience reached such a pitch that, when the author was called out at the close of the performance, some of his friends, not content with the usual signs of approval, dashed to the stage properties and crowned him with the paper crown used for Norma. This was the poet's last great success on the stage until twenty years later.

Nevertheless, each year continued to mark the production of two or three pieces, some of them original and some translations. Notwithstanding this rather large output, the author's pecuniary remuneration seems to have been small. Writing for the Spanish stage had, indeed, never been an especially lucrative occupation. In 1849 a law was passed which attempted to standardize and define the rights of authors and managers. ${ }^{3}$ Some of its paragraphs are worthy of being cited.

The Regulations Governing the Teatro Español, of February 7, 1849, read in part as follows:

Article 10: "The author of a new play in three or more acts will receive from the Teatro Español, during the period designated by the law concerning literary ownership, ten per cent. of the gross receipts of each performance, including subscription tickets.

- Published with Las millonarios by Don Antonto Garela Gutlérne, Madrid. 1881. 
This shall be three per cent. if the work has one or two acts."

Art. 11: "Verse translations will receive half of the percentage designated for original plays, and translations in prose one fourth."

Art. 13: "For the first three performances of a new play, the author, translator or adapter will receive ..... twice the normal per cent."

It must be observed that these stipulations apply to the Teatro Español, which appears to have been more liberal than the other theatres.

Article 59 of the Decree of February 7, 1849, Governing the Theatres of the Kingdom, reads:

"The author of a dramatic composition shall have a right to .... a definite per cent. of the gross receipts of each performance, including subscription tickets. The maximum shall be the per cent. paid by the Teatro Español, and the minimum one half as much."

Art. 60: "Authors shall have a right to occupy free of charge on the night of the première of their plays a box or six first class seats, and shall have a right to occupy one seat free of charge at each successive performance."

However, these regulations had not come into force until thirteen years after the performance of El trovador, and they were by no means as liberal as they might seem to the present-day reader, because the theatre-going public in Madrid was not large enough to warrant more than a few performances of even the must successful plays. The longest run secured by any of García Gutiérrez's 
plays was that of his Venganza catalona, in 1864, which continued for fifty-six nights." It may be readily understood, then, why the author should have grown discouraged in 1844 and have resolved to seek his fortune elsewhere. Like so many Spaniards before him, he decided to try the New World. Accordingly he embarked for Cuba, where he engaged in newspaper work in Havana. His position was an obscure one on the staff of the Gaceta Oficial which Piñeyro (El romanticismo en Espana, p. 107) calls the least literary publication in Havana. After a time he moved to Mexico, having a narrow escape from shipwreck on the way, and resided principally in Mérida de Yucatán. In these years he produced a few plays, in addition to a long poem entitled La conquista de Nueva España, dealing with the exploits of Hernán Cortés.

After an absence from home of five years, he returned to his native country no better off in fortune than when he left it. Official notice was beginning to be taken of his worth, however, and in 1855 he was appointed President of the Spanish Financial Commission in London. He was in that city when he received the news that his brother's house in Seville had been burned, and that his abovementioned poem La conquisla de Nueva España and a drama, entitled Roger de Flor which had engaged him for some time while in America, had both been ince. D. $v$.

- Ce. Obras escogides de D. Antowio Garcia Gutifrrez, pre- 
consumed in the conflagration. In 1857 he gave up his post in London and returned to Madrid to take up again his literary tasks. Comedies and light operas (zarzuelas) were interspersed among his more serious pieces; his best known zarzuela is El grumete, which, with music by Emilio Arrieta, was played at the teatro del Circo in 1853. He also continued to translate and adapt plays from the French stage.

In the year 1860 he produced an adaptation of Lessing's Emilia Galotti under the title of Un duelo a muerte, which so able a critic as Piñeyro considered by no means an improvement on the original and which did not enjoy a very great measure of success. ${ }^{5}$

It is not infrequent that authors in their maturer years return to the more extravagant vein of their youth and win success thereby. Precisely this happened to Garcia Gutiérrez in the year 1864. The theme of his lost drama Roger de Flor, dealing with the expedition of that chieftain and his Catalan compatriots in the Orient from 1302 to 1311 , continued to attract him, and on it he constructed a new play, giving to it the title of Venganza catalana. It was presented at the Teatro del Príncipe on February 4, 1864 and achieved great success, running, as has been stated, fifty-six nights. This was his last great play; those following show a marked

- Cf. El romanticismo en España por Enrique Piñeyro: Paris, Garnier, 1904. pp. 108-109. 
decline in creative power and poetic inspiration, though be continued to write for twenty years longer. In his later years a number of honors came to Garcia Gutiérrez. He took his seat in the Spanish Academy in 1862. Various medals were bestowed on him. He wore the Great Cross of the order of Charles III, of that of Maria Victoria, of Isabel la Catolica, and of the Concepción de Villaviciosa of Portugal. In 1868 he was appointed Spanish Consul at Bayonne, and the next year at Genoa. From 1872 onward he was Director of the Archaeological Museum of Madrid. His death occurred on August 26, 1884. 

CHAPTER II.

\title{
The Advent of the Romantic Drama
}

\author{
IN SPaIN.
}

The Romantic movement in Spain, as in other lands, arose as a protest against a period of literary rigidity immediately preceding it. If its triumph in Spain seemed more rapid than elsewhere, this was due in large part to political conditions; and the movement, once started, exhibited much the same features as in France. Yet there are certain special conditions in the literature of Eighteenth Century Spain which are worthy of consideration.

The whole period from the end of the Siglo de Oro through the first third of the Nineteenth Century was a singularly barren ot 2 . The sources of inspiration which fed the tremendous vitality of the Golden Era in Spanish letters seemed to dry up, and no fresh Renaissance arrived bringing with it renewed inspiration. The principles on which the Spanish comedia was based were broad and liberal, with a tendency toward excessive freedom and exaggeration; after Calderón, there was no possible 
further development of these principles except along the line of further exaggeration. Calderón's less inspired imitators drove their vessel on the rocks with their extravagant plots and their euphuistic and bombastic verbiage. Those who hoped to reform the theatre by applying to it a set of strict rules and precepts based mainly on French models were unfortunate in being unable to write acceptably according to their vaunted principles. The younger Moratin was the one bright star in their constellation, but he came late in the Eighteenth Century, wrote comparatively few plays, and had no numerous following.

The Eighteenth Century was one of learning rather than of imagination. It was this century that marked the foundation of the Spanish National Library (1711), the Royal Spanish Academy (1714), the publication of the Diccionario de Autoridades (1726-1739) and the foundation of the Academy of History (1738). Enrique Flórez himself wrote most of the monumental España Sagrada, of which the publication was begun in 1754; in 1800-1805 the philologist Hervás published a Catálogo de las lenguas de las naciones conocidas containing the names of more than 800 languages; Masdeu published a twenty-volume Historia critica de España in 1783-1800. Many works were devoted to the discussion of the rules of poetry and the drama. In a word, the critical rather than the creative spirit was the dominant one. 
In general this spirit of criticism championed the dramatic canons of Seventeenth Century France as against the freedom of the Golden Era in Spain. One would naturally think that the accession of Louis XIV's grandson as Philip V of Spain, in accordance with the provisions of the Treaty of Utrecht (1713), had much to do with this turning toward France, but the coming of the Bourbon dynasty was by no means the sole cause. Menendez y Pelayo says: ${ }^{\circ}$

"It may be affirmed without fear of seeming paradoxical that the change of dynasty was not the event which most efficiently brought about the change in our literary customs and tastes which took place during the (Eighteenth) century, and that the same change would have been realized sooner or later, with greater or less intensity, even if the dynasty of Austria or any other than the French had prevailed in Spain."

The eminent critic goes on to comment on the influence of French literature in Eighteenth Century England, Germany and Italy, and refers to Spain in these words:

"We Spaniards need not be ashamed, therefore, of having received, perhaps in less degree than other nations, an influence which, in the state of prostration and depression existing in our literature, could not fail to be beneficial, and which, moreover, came

- Hiotoris de las ideas eattinas en Eapafia, ed. 1886, tomo III. p. 287. 
as a recompense for the influence which we had exercised in France from the second half of the Sixteenth Century up to the second half of the Seventeenth."

Moreover this study of French literature in Spain in the Eighteenth Century was not something that began overnight; it had its roots in the Seventeenth Century. Lope de Vega praises Ronsard; Quevedo translated St. François de Sales' Introduction à la vie dévote, and often quotes Montaigne, of whose essays there was a Spanish translation in the Seventeenth Century. Diamante adapted Corneille's Le Cid under the title of El honrador de su padre. El labrador gentilhombre, an imitation of Le bourgeois gentilhombre, was played at the Retiro on March 3, 1680. Mlle. De Scudéry's Artamène, ou le Grand Cyrus, was translated into Spanish in the time of Charles II. The Spanish theatre, with which we are more particularly concerned, continued the tradition of the Seventeenth Century in the first part of the Eighteenth, but mainly through exaggerated imitations and adaptations by such men as Zamora, Fernández de León and Cañizares. Zamora and Cañizares also wrote comedies called "comedias de figurón (caricatures); Menéndez y Pelayo tells us (op. cit., p. 297) that, though these works were of native inspiration, they bore sufficient resemblance to the plays of the school of

¿ Menéndez y Pelayo, op. cit., p. 293. 
Molière to save them from the condemnation of the Francophile critics as well as from the general proscription which fell on the Spanish "ancient and marvellous theatre."

Throughout the Eighteenth Century there was a current of national literary taste in Spain which opposed the strict trans-Pyrenean standards, but this opposition had to struggle hard to assert itself. The old Spanish freedom and exuberance began to be fettered by artificial literary rules and regulations, and the upholders of French models did their utmost to establish their system. Luzán, Montiano, Nasarre, Garcia de la Huerta, Jovellanos and the Moratins in general condemned the freedom of the Spanish theatre in the Siglo de Oro and endeavored to establish in Spain the neo-classic doctrines of Boileau and Le Bossu. They admitted that some of the plays of the Golden Era had merit, but implied that they would have been very much better if Lope and his fellow-dramatists had strictly observed the unities. The more violent followers of Luzan had only harsh words for the older theatre of Spain. Blas Antonio Nasarre, for example, considered Calderón's autos as comic interpretations of the Holy Scriptures, and referred to Lope as the "odioso heresiarca o corruptor de la dramática española."

At all times, however, there were some who defended Spain's past literary glories and who opposed the invasion of French taste. Padre Feijón believed that a poet should write according to his own genius 
and not be bound by a set of fixed rules. Zavaleta wrote a reply to Nasarre in which he stoutly maintained the worth of the old Spanish national theatre. The earlier numbers of the Diario de los literatos de España (1737-1742) were decidedly favorable to the dramatists of the Siglo de Oro. The discussion continued up to the time of the triumph of the Romantic movement. On the whole the supporters of French taste had rather the better of it as far as the cultured class was concerned; plays of the school of Lope remained in favor with the people. A full account of this contest is given by Menéndez y Pelayo, Historia de las ideas estéticas en España, Siglo XVIII.

While these discussions about the Spanish theatre were going on, what was actually happening on the Spanish stage? Men like Luzán and his compeers wished to reform the theatre from above, but the Spanish stage has ever responded to popular rather than to academic inspiration. This popular tradition continued all through the Eighteenth Century and was fanned into flame by the Romantic movement in the Nineteenth. It will be well to take a brief glance at the Eighteenth Century theatre, for it will show that, while public taste may not have been admirable, it at least opposed the imposition of standards foreign to the tradition of Lope and Calderón, and showed great appreciation for playwrights as distinctly native in inspiration and flavor as Ramón de la Cruz. 
First of all, the plays of the Golden Era never ceased entirely to be represented; they have always held the boards to a greater or less degree from the time of Lope de Vega to the present day. Moreover, then admirers continued to write plays in imitation of theirs, and these plays succeeded with the populace. Unfortunately these imitators were not men of remarkable genius, and the worth of their productions was comparatively not large. By the time of the death of Charles II the Spanish theatre had reached a very low ebb. The causes of this decline are not far to seek, for the decadence of Spain in literature paralleled its decline in all other lines. The force of the Renaissance had spent itself and no external influence came to replace it. The course of Spanish poetry was circumscribed, and no further vasiation was possible within that course; hence, if there was a dearth of genius the plays of the same sort which continued to be written necessarily showed a lack of originality and freshness. The drama in the latier part of the Siglo de Oro tended toward more and ever more exaggeration; imitation of this spirit could, in the hands of secondrate writers, be nothing but further and wilder exaggeration. In the Siglo de Oro, poets spoke to a people united spiritually as well as politically; men of high and low estate had the same religion, the same politics, and much the same aspirations. After 1713 the house of Bourbon was at the head of the government, and men of higher culture began to 
espouse French literary principles; there was a struggle, as we have related above, between those who wished to maintain the old traditions and those who wished to impose strict literary standards such as those of Seventeenth Century France. The traditionalists had rather the better of it in the first half of the century, before the French movement had gained sufficient momentum; and the Gallicists thereafter.

The best followers of the old school were Cañizares and Zamora. José de Cañizares (1676-1750) is famous for his adaptations of the works of Lope, to whom he owes his best piece, El domine Lucas. Of his eighty-odd published comedies the majority belong to this style; he also wrote a few, such as El sacrificio de Ifigenia, which were modeled on the French school. His contemporary, Antonio de Zamora, declared that his main effort was to follow in the footsteps of Calderón. He succeeded in imitating the form but not the spirit of his master. In addition to these two there were numbers of men of less inspiration who filled the stage with their wildly exaggerated extravagances, abounding in all the melodramatic paraphernalia of shipwrecks, duels, disguises, miraculous appearances of Saints and extraordinary adventures of all sorts, mixed together to form a faint resemblance to a plot.

In view of this degeneration of the popular stage, it was natural that there should be endeavors to improve its tone. Such were the efforts made by 
the writers of Poetics whom we have mentioned, e. g., Luzan, Montiano, Nasarre. To the success of the efforts of most of them, there were two very serious hindrances. The first was, that instead of reforming the Spanish theatre according to its own tradition, they endeavored to impose on it a set of foreign rules; and the second, that they were unable to write plays themselves which were of sufficient value to make their example count. Montiano's Vir. ginia, Alaviljo, N. F. de Moratin's Petimetra, Hormesinda, José Cadalso's Sancho Garcia and the like, were not of a nature to serve as models. Attempts were made also to adapt the old Spanish masters to the new rules, notably by Cándido Maria Trigueros, who adapted Lope's La Estrella de Sevilla and El ansuelo de Fenisa, and by Sebastián y Latre, who adapted Rojas' Progne y Filomela and Moreto's El parecido en la corte." The public's affection for the older dramatists was so great that they forced the actors to repeat $E$ l parecido en la corte next day in its original form.

In the middle and latter part of the century there were many who followed the example of Cañizares and Zamora; their productions found favor with the populace, but were of such slight value that they have not survived. Such men were Moncín, Valladares, Comella, and Zavala y Zamora, all of them

- Hiatoria de la literatura y del arte drandtico on Eopala, por Adolfo Federico Conde de Schack. Tr. por Eduardo de Mier. Madrid. 1887. Vol. V. p. 833. 
the sort of authors whom Moratin satirized in his Comedia nueva.

The only follower of the old tradition whose works have received general commendation was Ramón de la Cruz (1731-1794). Continuing the tradition of the old pasos (curtain-raisers) and entremeses (interludes) he wrote sainetes (farces) full of life, vigor and color, without literary pretensions but admirably portraying all phases of the life of the lower social strata of Madrid. The few works in which he followed French models are forgotten. He not infrequently took occasion to poke fun at his serious rule-bound contemporaries. His field was narrow, but he is the best representative of the gay, spontaneous, exuberant native wit which Lope and his school possessed and which the Eighteenth Century classicists so sadly lacked.

The man best able to reform the Spanish theatre was one who did actually undertake the task and who devoted much energy to it: Leandro Fernández de Moratin. $\mathrm{He}$ is the outstanding dramatic genius of his century, who might have brought about at least a temporary reform if he could have produced enough plays to exemplify his principles; but his output was small, and he had no successors who persisted in his methods. His Comedia nueva (Feb. 7,1792 ) satirizes violently the playwrights of his time, but it did not destroy the objects of its attack, who were too numerous and fecund. The play is not a satire of the plays of Cañizares and Zamora, nor 
of Ramón de la Cruz, but of their wild contem. poraries. Moratin seems particularly distressed that foreigners may judge Spain by the mad plays which he satirizes; witness the speech of Don Pedro in Act I, scene 3: "And this stuff is played in a cultured nation? And this is printed, for foreigners to make sport of us?" Moratin's opinion of the plays he attacks may be divined from what Don Pedro says of the work of the poetaster Don Eleuterio (Act II, sc. 7):

"Es increible. Ahi no hay más que un hacinamiento confuso de especies, una acción informe, lances inverosímiles, episodios inconexos, caracteres mal expresados, o mal escogidos; en vez de artificio, embrollo; en vez de situaciones cómicas, mamarrachadas de linterna mágica. No hay conocimiento de historia, ni de costumbres; no hay objeto moral, no hay lenguaje, ni estilo, ni versificación, ni gusto, ni sentido común."

Yet no one style of play held the stage to the exclusion of others. One day there might be a drama of Lope or Calderón; the next, an opera (the opera came into vogue through Isabel Farnese, second queen of Philip V); the next, a comedy of Molière, Regnard or Goldoni; and then a play by Comella, Moncin or Valladares.

The conflict of the church with the theatre in the Eighteenth Century is an interesting phase of literary history too long to be entered into here. Suffice it to say that the theatres were closed in 
the provinces at various times all through the century, and Ferdinand VI issued very strict regulations against the theatre, - which were never strictly applied. The Inquisition issued a list of nearly six hundred plays whose performance was forbidden, and in it was included Calderón's La vida es sueño, El tejedor de Segovia, and many others of the best dramas of the old school. It has been suggested that this ostracism of the old masters was due to the influence of those who supported the French doctrines and who tried by this means to promote their own cause.

The total dramatic activity in the Eighteenth Century was much less than in the Seventeenth or Nineteenth. The younger Moratín published a list of authors and plays of the Eighteenth Century in the preface to his Comedia nueva. ${ }^{10} \mathrm{He}$ mentions a hundred and seventy six authors and about fourteen hundred plays of all sorts which were either represented or printed between 1700 and 1825. This number seems quite small as compared with the list published by J. E. Hartzenbush ${ }^{11}$ of more than five hundred authors of plays between 1836 and 1866 .

The early years of the Nineteenth Century, mark-

- Cf. Ticknor, Hist. of Span. Lit., New York, Harpers, 1854 : vol. III, chap. vii.

10 Cr. Comedias de D. Leandro Ferndindez de Moratin, con el prólogo y las noticias de la Real Acamedia de la Historia. Paris, Baudry, 1838. Pp. xxili-xxxí.

1 Cf. Obras escogidas de D. Antonio Garcia Gutiérrez, Madrid, 1866. Pp. xvil-xx. 
ing the Spanish struggle (1808-1813) to throw off the French political yoke, were hardly propitious to literature of any sort. The classicists exerted the most powerful influence. Moratin continued to preach by precept and example. His adaptation of Molière's L'école des maris (La escuela de los ma. ridos) was produced at Madrid in 1812, and his adaptation of Le médecin malgré lui (El médico a palos) in 1814. Quintana was a pronounced clas. sicist. We have already mentioned the neo-classical dramas of Martinez de la Rosa and the Duke of Rivas. Jovellanos' neo-classical piece Pelayo (written about 1769 but played for the first time under the title of Manuza in 1792) was not especially successful, but his play El delincuente honrado (1773), based not on classical principles but on Diderot, was one of the greatest successes of the century.

The romantic movement in Spanish, as elsewhere, was a protest against strict classicism, a return to liberalism and individualism in literature. The outward manifestations were much the same in Spain as in France; but the relations of the Romantic theatres in the two countries with the theatres of their past periods of great splendor were quite different. The Romantic dramatists of France claimed to be opposed to the principles of the Seventeenth Century, for the French classic theatre was comparatively strict in its observance of a definite set of rules. The drama of the Siglo de Oro in Spain was much more untrammeled; very free in subject- 
matter and treatment, varied in form and very little bound by rules. It was popular rather than academic, exuberant rather than restrained. Obviously the Spanish Romantic dramatists were closer in spirit and in performance to Lope and Calderón than were Victor Hugo, Dumas père, Alfred de Vigny and the others to Corneille and Racine. The attitude of most of the Eighteenth Century classicists in opposing the older Spanish theatre was logical, for the systems of France and Spain were quite opposed to each other.

We have endeavored to point out the condemnation that was pronounced in the Eighteenth Century on the older Spanish theatre because of its disregard of the unities. When the French Romanticists made such an uproar about the unities, they were commending the old Spanish freedom in that particular; when Victor Hugo in his famous preface to Cromwell, raged against the unities of time and place, saying that the unity of action was the only one tenable, he was simply confirming the principles and practices of the school of Lope, whose plays suffer so sadly when judged by the strict standards of Boileau. Lope observed the unities of time and place only when it seemed quite plausible to do so. The disregard of these unities, as urged by Victor Hugo, was in Spain only a return to traditional practice.

Pierre Nebout, in his study Le drame romantique (Paris, 1895) defines Romanticism as a "return to 
lyricism." Here again the older Spanish and the Romantic theatres are more closely akin, for the classic theatre of France contained a smaller lyric element than that of Spain.

These are not the only respects, however, in which the Spanish Romantic theatre was closer to the theatre of the Golden Era than the French Romantic theatre to that of Corneille and Racine. The French Romanticists, with Victor Hugo at their head, endeavored to oppose as far as possible what had gone before them in the Classic Age. Lanson'12 says:

"Au theitre, comme partout, le romantisme se détermine d'abord par opposition au goùt classique; le premier article de la doctrine est de prendre le contre-pied de ce qu'on faisait avant."

One of the most conspicuous points of this opposition to classic practice was the abandonment of distinct dramatic genres in favor of a mixed form containing both tragedy and comedy. "The grotesque and the sublime" must be mingled, says Victor Hugo in his preface to Cromwell. ${ }^{13}$

"Car la poésie vraie, la poésie complète est dans l'harmonie des contrastes - tout ce qui est dans la nature est dans l'art."

This mixing of tragedy and comedy was common

32 Histoire de la litterature frangabe, 6e partie. Lirre II. Chav. Iv.

is P. 26 of the edition of Hermani and Crownell by the Imprimerte Natlonale. 
enough in the French drama of the Middle Ages and in the plays of Hardy and his contemporaries in the first years of the Seventeenth Century, and Lanson points out that this mingling of genres had been seen in the Eighteenth Century, in a different sort of drama, in the works of Diderot and Beaumarchais. Nevertheless the system in vogue from 1640 until the Romantic Movement, was strongly opposed in general to this admixture, and the classic ideal had become a national one which lasted for more than two and a half centuries. Such an admixture of comic and tragic elements was quite usual in the older Spanish theatre, however, and was never quite superseded by the Eighteenth Century classical system. When the plays of Lope, for example, were "adapted" by classicists like Trigue-ros, the rôles of the graciosos were suppressed. Victor Hugo was by no means the originator of the idea that, since life is a succession of small tragedies and comedies, the drama should take this into account; the older Spanish and English theatres had practised the principle long before his time.

The French Romantic plays, in practice even more than in theory, contained a much larger melodramatic element than the classic drama. Some of the Romantic plays, such as Hugo's Lucrèce Borgia, Marie Tudor, Le roi s'amuse, and many of the elder Dumas', such as La Tour de Nesle, Henri III et sa cour, are melodramas pure and simple.

The interest depends on a rapid succession of 
stirring events and not on a study of character or passion. The Spanish Romantic and the Spanish classic theatres were closely akin in this respect. The Spanish plays of the Siglo de Oro were much more episodical in character, much more diffuse and prodigal of action that the French plays of the Seventeenth Century. Take for example Guillén de Castro's Las mocedades del Cid or Lope's El reme. dio en la desdicha, or Calderón's El tejedor de Se. govia, or Tirso's Ed burlador de Sevilla.

The older Spanish plays were more Romantic in their tendencies also on account of the greater development of their characters as individuals. The Cid of Guillén de Castro's play is an individual and not a type like Corneille's Cid; the Spanish comedias are not studies of the human will or of its conflict with passion. Calderón's mayor of Zalamea is an individual figure; the heroes of Lope's Fuenteovejuna are sturdy individuals fighting for their rights.

In the matter of versification the Spanish theatre has ever been freer than the French. Hugo states in his preface to Cromwell that verse is a visible form of thought, which is obvious enough, and continues:

"Nous voudrions un vers libre, franc, loyal, osant tout dire sans pruderie, tout exprimer sans recherche... plus ami de l'enjambement qui l'allonge que de l'inversion qui l'embrouille; fidèle à la rime, cette esclave reine, cette suprême grâce de notre poésie, 
ce générateur de tout mètre... Il nous semble que ce vers-là serait aussi beau que la prose."

It is not for us to explain the last curious statement; at any rate the manifesto contains nothing contrary to the rules and practice of Lope de Vega, to whom it would have seemed illiberal rather than over-bold. Hugo was satisfied to use only the Alexandrine in his plays, even if he did make it more flexible, but from the earliest times the Spanish dramatists had had a considerable number of metres at their disposal. Lope's counsels are often quoted: use décimas for sad passages, he says; the sonnet for suspense; romances, which may be used in octaves, for narration; tercets for graver episodes; and the redondilla for love passages. As for the enjambement, there was never anything shocking about it in Spain, where it was a commonplace. Some of the syllables of the same word, even, might stand at the end of one line and the rest of the word at the beginning of the next line. Cf. Calderón's La niña de Gómez Arias:

Pues ¿qué cosa hay más imper-

Tinente que la pobreza? ${ }^{14}$

The general characteristics of the Romantic theatres of France and Spain were substantially the same; both had the same virtues and the same defects. Both marked a return to lyricism in the

-2 Quoted by G. Huszár, L'influence de l'Espagne our le theatre français des XVIII et XIXe siecles. Paris, 1912. 
drama, and both present the passions and strivings of the individual as shown by a series of episodes: they treat of the individual and not of the general. Both are liable to the same melodramatic excesses, to the same exaggeration of Romantic passion. Both are interested more in the action for itself than in the psychological analysis of motives. Both go mainly to the Middle Ages for their background, throwing over it a colorful glamour under the guise of historical verity.

We have already mentioned Padre Feijó's doctrine that poets should develop their own genius in their own way. As we consider the immediate precursors of Romanticism in Spain we find much the same doctrine in the works of Dionisio Solis. Solis is generally regarded as a classicist, but certain of his ideas are extremely liberal and coincide with those later emphasized by the Romanticists. Preceding his translation of Alfieri's Orestes (1807) there is a prologue which amounts almost to a Romantic manifesto. He begins by stating that the French and Italians tried to put limits on the arts, "usque quo et non amplius," and that they sometimes appeared to think that the worth of a play was in proportion to its adherence to a set of rules. Such a restriction as this Solis thinks must lead to a checking of genius and ultimately to barrenness, for be believes that all rules should be modified to suit the customs, ideas, character, climate and occupations of the various nations. 
The most vigorous defender of Spain's ancient glories and promulgator of Romantic ideas was not a Spaniard, but a German. Coming to Cadiz as consul in the second decade of the Nineteenth Century, Böhl de Faber brought with him the doctrines of William Schlegel and began to spread them. William Schlegel had given his course in dramatic literature in Vienna in 1808, and in it had lauded to the skies the genius of Calderón and the older Spanish theatre in general. His knowledge of the objects of his praise is said by Menéndez y Pelayo to have been very superficial, ${ }^{15}$ but he undoubtedly helped to bring the masters of the Siglo de Oro back into general esteem. Böhl de Faber had a five year controversy (1814-1819) with José Joaquín de Mo$\mathrm{ra}$, a representative of the classicists. The former wrote in the Diario mercantil of Cadiz, the latter in the Crónica cientifica y literaria of Madrid. Similarly liberal ideas were championed in the journal $\mathrm{El}$ Europeo, founded at Barcelona in 1823.

The individual and sentimental literature of France, Germany and England had already begun to penetrate Spain. An arrangement of Goethe's Werther was published as early as 1797 by José Mor de Fuentes; Chateaubriand's Atala appeared in translation in 1803; Bernardin de St. Pierre's Paul et Virginie in 1818, the year which marked the publication of a series of translations of French,

is Op. cit., vol. VII, pp. 211-214. 
English and German modern novels by Cabrerizo at Valencia. But the number of translations is not as important as the fact that the educated class read the new Romantic literature as it appeared in France, and in French translations of English and German works. This naturally helped to wean educated Spaniards from neo-classical tastes, and made them better prepared for the Romantic plays when they appeared on the stage.

Not a few of those who afterwards became leaders in the Spanish Romantic movement had all too good an opportunity to familiarize themselves with what was going on abroad, for they spent various periods in exile. The Duke of Rivas spent his exile (1823-1834) in England, Malta, Italy and France. Espronceda spent long periods in England and France. Martinez de la Rosa passed eight years in Paris. Larra received his early education in France, as did Gil y Zárate. These men and lesser lights were permitted to return after the death of Ferdinand VII in 1833, and the triumph of Romanticism followed promptly.

The young men who were left in Madrid formed in the year 1830 a sort of Cénacle of their own at the Café del Principe, calling themselves "El Parnasillo." 16 They were of course friendly to new ideas, and their number included many of the standard-bearers of the Romantic movement. Among

3. A full account of the "Parnasillo" is given by Mesonero Romanos, Memorian de un octentón, Madrid. 1880. Chap. XXI. 
them were Ventura de la Vega, Escosura, Gil y Zárate, Bretón de los Herreros, Larra, Grimaldi, afterwards reinforced by Espronceda, Hartzenbusch, García Gutiérrez, Zorrilla and many others.

None of the above authors themselves produced Romantic dramas up to the year 1835, but the Spanish stage began to exhibit many works of Romantic tendencies coming from France. These were, first, importations from the Porte-Saint-Martin in Paris, of the melodramatic predecessors of the Romantic dramatists of France, such as Caigniez, Ducange and Pixérécourt. Le faux Stanislas, Edouard en Écosse ou la nuit d'un proscrit, Les mines de Pologne, Le chien de Montargis, Les ruines de Babylone and La pie voleuse were all played in Madrid before 1825. Atalá o los amores de dos salvajes was produced about 1830, the year in which Bretón adapted Ducange's Le couvent de Tonnington. Larra translated the Robert Dillon of Ducange in 1832.

It is a strange occurrence that the first Romantic drama written by a native Spanish author was produced by a man of such strictly neo-classical beginnings as Martínez de la Rosa. He was in Paris in the late twenties, and was young and impressionable enough to become a convert to the new dramatic school, and to write two dramas in the Romantic style, Aben Humeya and La conjuración de Venecia. Aben Humeya was written in French and presented with some success at the Porte-SaintMartin in 1830. In the preface to the play, Mar- 
tinez speaks of the desirability of historical accuracy, of local color and of a style full of imagery - a very mild Romantic manifesto, for the author was ever on the side of moderation. Aben Humeya takes as its subject the revolt of the Moors under Philip II. In the first scenes we learn that Aben Humeya, a descendant of Mahomet, and a man of mild character, is goaded by continual oppression on the part of the Spanish monarch to plan a revolt. He discovers that his wife's father had reached a secret agreement with the envoy of the Castilian CaptainGeneral; he therefore forces his father-in-law to drink poison. But Aben's personal enemies start a revolt against him; they succeed in killing him just as his wife rushes in, crying, "My father! What have you done to my father?" The drama is in three acts and in prose; the unities of time and place are not strictly observed.

When Martinez reached his native country, he decided to try there a drama in the new fashion, and his Conjuración de Venecia had its première in Madrid on April 23, 1834. Like Aben $\mathrm{Hu}$ meya, it is written entirely in prose, but there are five acts instead of three. The unity of time is not observed, for the action involves four days; the unity of place is recognized to the extent that the entire action takes place in Venice. Rugiero, an unknown adventurer, is planning a bloodless revolution against the Doge of Venice, Pedro Morosini. Rugiero is secretedly wedded to Laura, daughter of Pedro's 
brother Juan. Rugiero, in an interview at night in a cemetery, is telling his wife of his plans against her uncle, when Pedro Morosini and his agents seize him; they have overheard all his plots. At the trial it is revealed that Pedro Morosini, who presides as Doge, is Rugiero's father. Morosini faints, Rugiero is condemned and not even allowed to see his father before being executed.

Here is a drama, then, quite after the manner of the French Romantic dramatists. The melodramatic element is very conspicuous, and the rest of the Romantic appurtenances are all there.

Five months after the appearance of La conjuración de Venecia Larra produced a drama which was much more violently Romantic. This play, Macias, is a good example of the close relation between the Spanish classic theatre and the Romantic, for the story of the unfortunate Macias was treated by Lope in his Porfiar hasta morir, printed in 1638. The play will be considered in some detail when we come to treat it in connection with $\mathrm{El}$ trovador in the next chapter. Suffice it to say that Larra endeavors to put into practice all the canons of the Romantic drama in France, though he modestly says in his preface (for, like Hugo and Dumas, he issues a sort of manifesto in his prefaces):

"This is a sort of dramatic composition to which it would be difficult to give a name. It is not a play after the manner of Lope or Calderón; not a Classic play; not a Greek tragedy... Is it a pale 
reflection of the colossal, naked school of Dumas and Hugo? I do not know what resemblance the critics may find between my feeble work and Antony, Lucrèce Borgia, Henri III and Le roi s'amuse. . . Macias is a man who loves, nothing more. . To portray Macias as I imagined he might or should have been, to develop the feelings he would have had in the frenzy of his mad passion, and to depict a man, such was the purpose of my drama." "

Hartzenbusch tells us that the play was presented "con grandes aplausos." is

March 22 of the following year (1835) saw the presentation of a play still more unrestrainedly Romantic, the Duke of Rivas' Don Alvaro o la fuerza del sino. Its success at first seemed doubtful (Hartzenbusch, $o p$. cit.), but was later fully assured. A more exireme example of what a Romantic play can be at its wildest would be hard to find. ${ }^{10}$

The next Romantic play to take the boards, at the end of the year 1835, was Pacheco's Alfredo. The theme is not unlike that of Don Alvaro; Alfredo's father is reported to be dead, and Alfredo falls violently in love with his widow Bertha, and kills her brother when the latter interrupts a night interview of the lovers. As Alfredo and Bertha are about

"Obras completas de Figaro, 2dn edición, Paris, 1857. vol. Ii. p. 480.

1O Ob. eace de Don Antonlo Gareia Gutlérrez, preface, D. Xv.

10 A synopeis of this play is given and the play discused at

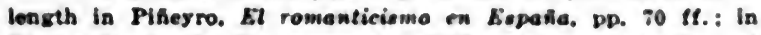
Blaneo Garda, La lit. eop. en el S. XIX, vol. i. pp. $144 \mathrm{fl}$. : and Karl A. Recrenaburzer, Uber den Trovedor dea Garela Gutitrrez, Dp. $491 \%$. 
to be married, the form of the murdered brother appears and tells them that Alfredo's father is not dead. The father does in fact return; Alfredo murders him when he himself is deserted by Bertha, and, in turn, crying "A curse upon me," stabs himself. ${ }^{20}$

Martínez de la Rosa's Aben Humeya, mentioned above, met with very little success when it was shown in Madrid early in 1836. Now that the Romantic drama had come into vogue, this production of the disciple of moderation must have seemed insipid. Though it was constructed on the general principles of the Romanticists, it was far from containing the melodramatic extravagances of Don Alvaro.

In addition to these plays by native authors, the Spanish stage was flooded with translations from the French. The year 1835, for example, saw the production in Madrid of translations of Casimir Delavigne's Les enfants d'Edouard and of Hugo's Angelo and Lucrèce Borgia. Hugo's Hernani and Dumas' Thérèse, Catherine Howard, Antony and La Tour de Nesle came in 1836.

Larra $^{21}$ gives us an interesting picture of the state of the Spanish stage in an article published in the Revista de España of April 3, 1835. He tells us that the stage was then occupied by (1) the old drama, meaning anything prior to Comella; (2) the

20 Cl. Regensburger, op. cit., pp. 5152.

28 Obras de Larra, Caracas, 1839, vol. I, p. 236. 
melodrama from the Porte-Saint-Martin; (3) its elder brother the sentimental drama; (4) the classical comedy of Molière and Moratin; (5) the neoclassical tragedy; (6) translations from Scribe and his school; (7) the historical drama; and "not to forget anything", as Larra says, (8) the Romantic drama :

"nuevo, original, cosa nunca hecha ni oida... descubrimiento escondido a todos los siglos y reservado sólo a los Colones del siglo XIX. En una palabra, la naturaleza en las tablas, la luz, la verdad, la libertad en literatura, el derecho del hombre reconocido, la ley sin ley."

Notwithstanding this hit at the Romanticists, Larra himself shortly afterwards writes a Romantic play.

It was at this juncture that a new author, Garcia Gutierrez, appeared with $\mathrm{El}$ trovador to join the Ro. mantic cohorts. 



\section{CHAPTER III.}

First Drameatic Attempts and "El Trovador"

The literary education of Garcia Gutierrez was necessarily that of the pseudo-Classic Eighteenth Century, for at the time there was no other sort in Spain; thus it was only natural that his earliest works should show this influence. But these early productions, consisting of a few poems and of a dramatic phantasy called $F$ ingal, also show his natural tendencies towards Romanticism. Along with imitations of the Eighteenth Century poet Meléndez he has to his credit translations of Victor Hugo and imitations of the old Spanish ballads. These poems were published in 1840,22 but many of them bear dates prior to 1835 , the year when El trovador was written.

We are told by Cayetano Rosell ${ }^{23}$ that Fingal was one of the plays which Garcia Gutierrez brought with him when he ran away from home and came

a Pocolas de Don Antomio Gereía Gutidrres, Madrid. Bolx, 1840.

"I In Awt. dram. contem. Introduction to Juon Lorensa. 
to Madrid. It is written in five acts, in romance heroico verse throughout. The assonance through all the first act is é-o; through the second, á-o; through the third, i-o; through the fourth, é-a; and through the fifth, á-a. The verse is well constructed, though the maintenance of such assonance schemes through whole acts leads to monotony. ${ }^{24}$

The play is composed in a highly tragic and sentimental, not to say lachrymose vein; there is not the faintest sign of the intermingling of comedy and tragedy, and no relaxation of the style noble. The first four lines give the key to the sentiment, style and mood of the whole play:

"¡Yo no más te veré, querida madre De Bosmina infeliz! Nunca tu seno A estrechar volveré, ni más la calma Veré dichosa en tu regazo ledo."

A brief outline of the play may be given as follows:

Bosmina, who has never known her father, is now lamenting at the fresh grave of her mother Morna. The Celtic king Rino and his son Fingal return from a victorious war. Fingal is passionately in love with Bosmina and she with him, but Rino opposes their union. Oppressed by a sense of guilt, he confesses to his companion Sorglán that Bosmina is his own daughter, born to him of Morna, who he had brought home in captivity from a neighboring

2. For treatment of such verse-forms, see Andrés Bello. Ortología y métrica (vol. IV of Obras completas), Madrid. 1890. 
kingdom conquered by him years before. To avoid the impossible situation, Rino determines that Bosmina shall marry her despised suitor Dutcaron. Bosmina and Fingal are informed that they are brother and sister. In spite of this, their wild passion continues. Fingal, driven to madness, kills Dutcaron. When he comes on the stage with his dagger still bloody, Bosmina tries to calm him, calling him brother. Fingal exclaims:

\section{"... Mis delitos}

Morir me ordenan. . . sin tu amor. . oh rabia..." and stabs himself.

In the vast uncontrollable passion of Fingal we have a foretaste of Romanticism; as in El trovador, Macias, Los amantes de Teruel, we have lovers coming to grief through no fault of their own; they are victims of circumstances and blind fate. The unpleasant story of unnatural love of brother for sister has been familiar in literature from the time of the biblical narrative of Ammon and Tamar (II Samuel, 13) down to Chateaubriand's René. Chateaubriand had become popular in Spain from the very first years of the Nineteenth Century, ${ }^{2 s}$ and his work must have been known to all the Spanish Romanticists. On the other hand, there is no proof that Garcia Gutiérrez was acquainted with Ducis' play Abufar (1795) in which this situation figures. Here we have Farhan fleeing from the tent of his father Abufar because of an unnatural attach.

3. Cl. Fitamaurien-Kelly. Hiot. de la lit. eap., Parls. 1913. D. 108. 
ment for his sister Saléma - a love which she returns with equal ardor. The treatment of this unholy passion occupies most of the play, but at last Abufar reveals the fact that Saléma is a foundling and not really his daughter, and the lovers are happy. Except for the dénoûment the plays are similar; in both pieces the unities are strictly observed; the verse, sonorous at times, is in general uninspired. As for Garcia Gutiérrez's composition it is extremely monotonous throughout.

Like some of the authors in our preceding chapter García Gutiérrez, not at first succeeding in having an original play presented, tried his hand at translation. French works were becoming more and more popular in the theatres of Madrid; the inexhaustible Scribe could not fail to be included among the playwrights in vogue in Spain. The first play translated by García Gutiérrez was Scribe's Le Vampire: Comédievaudeville en un acte (en société avec M. Mélesville; Théâtre du Vaudeville, 15 juin 1820). The Spanish version was presented in Madrid at the Teatro de la Cruz on October 10, 1834. The play is quite characteristic of Scribe's humor, with its pleasant dialogue, its elements of surprise, and its light and ingenious plot.

The scene is laid in Hungary. Hermance had sworn eternal faith to her betrothed Adolphe; but he has been reported dead at least six months ago, and she is now the fiancée of the Baron de Lourdorff. 
Her sister Nancy reproaches Hermance for being willing so soon to forget Adolphe.

Adolphe's uncle, the Count de Valberg, has been assured of his nephew's death in Temesvar, and Lourdorff swears he saw him die there. However, Valberg is amazed at a conflicting report.

There is a rumor current in the neighborhood that the much dreaded vampires are abroad. Peters, the gracioso of the play, claims to have seen one lurking not far away. This vampire turns out to be Adolphe, who appears at the house, and learns of the infidelity of Hermance and of Nancy's constancy to his memory. He decides to invite himself to the wedding of Hermance and Lourdorff, during which he hides in a closet. Valberg declares at the ceremony that he is on the trail of his nephew; he feels sure that Adolphe is somewhere in hiding, and proclaims in a loud voice that if he could only see Adolphe, he would pardon him for his pranks. Adolphe thereupon comes out of hiding and receives his uncle's blessing. He insists that the marriage of Hermance and Lourdorif proceed, and is consoled by winning Nancy as his own bride.

The next translation from Scribe made by Garcia Gutiérrez was put on for the first time in Madrid in 1835, under the title Batilde o la América del Norte en 1775. The original, La Bohemienne ou l'Amerique en 1775, written in collaboration with M. Mélesville, had been shown in Paris at the Thêâtre du Gymnase in 1829. It was called "A historical drama in five acts." How "historical" it was is best shown by a synopsis: 
Henriette, daughter of the English Governor Gage, stationed in Boston, Mass., has fallen in love with the country of her adoption, and especially with one of its patriots namel Lionel Lincoln. Lionel is Colonel of the Virginia Dragoons, stationed at Boston. Lord Gage, however, suggests Lord Cokney, a ridiculous fop who is his new secretary, as being a much more eligible suitor. Gage, in fact, suspects Lionel and his friend Arthur Winkerton, a Captain in the same regiment, of sedition. $\mathrm{He}$ accordingly invites a Gipsy, Zambaro, and his niece Bathilde, to come to his mansion, and bargains with them to spy on Lionel and Arthur. They readily accept. Arthur is in a special degree persona non grata to the English authorities because he has recently killed an English officer in a duel. The Englishman had proposed a toast to England; Arthur had countered with a toast to America, and the duel followed.

In Act II, Lionel and Arthur are discussing their plans for an uprising against the English. They are counting on the aid of the Baron de Courville, whose ship lies at anchor in the harbor. Zambaro and Bathilde have begun work. Bathilde has found it easy to gain the confidence of Lionel, but he has proven so charming that she begins to regret her hateful task of spying on him.

Arthur is almost drowned as he attempts to visit De Courville's ship. Lionel, rushing to his aid, gives his wallet to Bathilde for safe keeping. Zambaro seizes it and finds in it a letter from De Courville.

Act. III. Bathilde begs Zambaro to give up his mission of spying on the conspirators, but he refuses. $\mathrm{He}$ is having great success; he uses the letter of De Courville to good advantage, and is masquerading as De Courville himself, learning more and more 
secrets from Lionel and Arthur. But Lord Cokney comes in, and seeing him in the presence of the two Americans, says, "Ah! The Gipsy!" Seized by Lionel and Arthur, Zambaro explains to them that he had pretended to Gage and Cokney that he was a Gipsy so as not to arouse suspicion. The explanation is accepted. Lionel happens to mention that he has a letter, written in German, for a certain Zambaro, but of course Zambaro is unable to claim it.

Henriette writes Lionel a note of warning that he is being trailed, and, coming to his inn escorted by Cokney, she pretends to swoon and gets the note to him.

A meeting of the revolutionists decides upon seven o'clock for a general uprising. Zambaro mutters that the leaders will all be arrested at five.

Act IV. Zambaro has discovered that Bathilde really loves Lionel, and seeks to help her by doublecrossing Gage. But the real Baron de Courville appears, and Zambaro is put in close confinement. Lionel confesses to Arthur his love for Bathilde. Bathilde sees Lionel, confesses to him her part in spying on him, and receives his forgiveness.

While Zambaro is held prisoner with a pistol pointed at him through a curtain, Cokney comes in and talks freely to him of Gage's measures to frustrate the conspirators. Lionel and Arthur therefore determine to begin the uprising immediately.

Act V. Bathilde learns from the letter to Zambaro that she is really the daughter of Lord Gage by an earlier marriage, and that she had been stolen by Zambaro's brother. The attack on the English has begun. Cokney is telling Gage of its progress when Lionel and Arthur burst in. Gage is saved 
only by the intervention of Bathilde, who comes in at this moment, and, revealing her identity, pleads with Lionel to save her father. Lionel asks Gage for her hand; but she says that Henriette is far worthier than she, and resolves to go to England with her father. Gage promises Lionel and Arthur to plead with the English parliament for America.

This play is fairly typical of the voluminous work of Scribe. The interest is entirely in the development of the plot. The characters are but puppets very hastily sketched. The episodical character of the play is its only point of contact with the Romantic drama. There is nothing to show that this or any other play of Scribe's exerted any profound influence on García Gutiérrez. Nevertheless, he translated one more play of Scribe's before entering the field with a drama of his own. Le Quaker et la danseuse was a one-act play written by Scribe in collaboration with M. Paul Duport, and was first presented in Paris at the Théâtre du Gymnase on March 28, 1831. García Gutiérrez's version appeared in 1835 .

Georgina Barlow, a dancer, pursued by all the gilded youth of London, has promised to marry Lord Darsie unless within a year she finds someone else she likes better. When the year has almost expired, a friend of the Quaker James Morton is injured in an accident and is brought to Georgina's house. Morton comes to see him there, and Georgina is much amused by his strict principles and somewhat chagrined by his failure to react to her charms. 
As they talk, Morton mentions the fact that he once rescued an orphan and placed ber in a home in Canterbury, whence she fled three years later with her dancing master. Georgina exclaims that she was the orphan, and explains that she fled to escape the scom heaped upon her, and that her dancing mastes was never anything more than a friend. Finally Georgina is so impressed by Morton's sturdy character that she decides to dismiss Darsie. The latter challenges Morton to a duel, but gives up the idea when Morton gives an exhibition of his strength, and his skill with the pistol. Georgina and Morton are happily united.

It was in this same year (1835) that Garcia Gutiérrez's most celebrated play was composed. El trovador finally appeared on March 1, 1836, at the Teatro del Principe. Though the play is well known, a synopsis is given because we shall wish to discuss it in considerable detail. The scene is laid in Aragón, and the time is the early Fifteenth Century.

\section{Jornada Primera. - El. Duelo.}

The first act takes place in the Aljaferia palace at Saragossa. Three servants of Don Nuño de Artal, Count of Luna, are talking together. Jimeno, the oldest, who has been in the service of the family for more than forty years, tells his two companions of strange events which occured in 1390. Don Lope de Artal, father of the present Count, had two children; Don Nuno was then six months old, and his brother Don Juan about two years. One night an old Gipsy woman, looking like a witch, came in and looked for a long time at the sleeping Don Juan. 
She was driven out, but from that time on the child grew weaker and weaker. The old Gipsy was caught and burned as a witch, and Don Juan immediately became better. Jimeno advised that the daughter of the Gipsy also be burned, but this was not done. Don Lope had great reason to regret it, for the child suddenly disappeared, and his charred skeleton was found on the spot where the witch had been burned.

Guzman, one of the other servants, has another tale to tell. Their master Don Nuño, says he, is wildly in love with Doña Leonor de Sesé, sister of the proud Don Guillén. She, however, is in love with a troubadour named Manrique, who is in the service of the Count of Urgel, claimant to the throne of Aragón. Nothing is known of Manrique's origin. On the night before Guzmán tells his story, Don Nuño secures a key to her apartment and determines to try to carry off Doña Leonor. Just as he is about to consummate his plan, he hears the sound of Manrique's lute. Manrique returns, thinkink Don Nuño to be some inquisitive squire. Doña Leonor comes down and, mistaking Nuño for the troubadour, leads him to the darkest part of the garden. But just then the moon shines out and Manrique sees the couple. He draws his sword and after a short fight disarms Don Nuño.

All this long exposition - in prose - is contained in the first scene, of about a hundred and forty lines. The rest of the first act, all in verse, takes place in Doña Leonor's chamber in the palace.

Leonor's brother Guillén reproaches her for loving a nameless troubadour and for scorning the illustrious Don Nuño. Guillén states that his word is given, and she shall marry Nuño or go into a convent. She says: 
Lo del convento más bien.

Guillin: ¿Eso tu audacia responde?

Leonor: Que nunca seré del Conde-

Nunca; ¿lo ois, don Guillén?

When Guillén leaves Leonor, she confesses to her companion Jimena her sorrow that Manrique is jealous of the Count and thinks her faithless. Manrique comes in, disguised, and hearing her expla. nation, reassures her of his love. He says he will see her no more until the arms of Urgel triumph. Don Nuño comes in before Manrique leaves, reproaches him with his low birth, and refuses to fight a duel with him. He is however finally provoked to consent, exclaming:

Trovador, no me insultéis

Si en algo el vivir tenéis.

Manrique: Don Nuño, pronto, salid.

Jornada Segunda. - El Convento.

A year has passed. Nuño and Guillén are in Nuño's apartments, lamenting the assassination of the Archbishop of Saragossa. Nuño has about recovered from the severe wounds which he received at the hand of Manrique in their duel. Manrique is reported to have been killed at Velilla. Guillén tells Nuño that Leonor is to take her vows this very day in the Convent of Jerusalem. Upon Guillén's departure, Nuño summons his servant Guzmán and orders him to abduct Leonor from the convent.

Don Lope de Urrea comes in to report that the partisans of Urgel have sacked Castellar and that a revolt is planned in Saragossa. Nuño is ordered to confer with the king. He commands Guzmán to use his sword even in the convent if necessary. 
When Guzmán is gone, Lope reports to Nuño a rumor that Manrique, supposed to be dead, is at the head of the rebels and has been seen in Saragossa.

The sixth, seventh and eighth scenes take place in the passage-way between the convent and the church. Leonor confesses to Jimena that she cannot forget the troubadour, and asks God's aid. Manrique and his servant Ruiz come in after the women leave, and wait in the hope of seeing Leonor. Guzmán and another servant of Nuño arrive. The religious ceremony. is heard, and the procession passes out of the church. Manrique raises his visor as Leonor walks by him; she falls fainting at his feet. Guzmán and his companion flee.

\section{Jornada Tercera. - La Gitana}

The first three scenes take place in a hut near Saragossa. The Gipsy Azucena is talking to Manrique. She tells him the story of the burning of her mother, who died crying for vengeance. She tells how she, Azucena, stole the child of the old Count of Luna. She was about to burn him on her mother's pyre, she says, when she was softened by the child's weeping. But then she seemed to hear anew the cry for vengeance; reaching out, she convulsively seized the child nearest her, and cast him into the fire: she had burned her own son instead of the Count's. Manrique, who had been reared by Azucena as her own child, says "Your son! Who am I then, who! ... I see it all." She immediately repents of having told the story and assures him that she said it merely to mock his ambition and test his love for her. Manrique assures her he loves her unswervingly. Ruiz enters to tell him that all is in readiness, and they depart. 
Azucena laments his leaving without even bidding her farewell, and vows he shall never know the truth of his origin. "Why did I save his life," says she, "except in order that he might be a son to me?"

In scene four, Leonor is kneeling in prayer in her cell. She confesses to God that she cannot drive Manrique's image from her mind. As she ends her prayer, she hears the singing of the troubadour himself. He comes in, and protests his deep love for her, persuading her that she has sworn him eternal faith which cannot be broken. Says he:

¿No me juraste amarme eternamente Por el Dios que gobierna el firmamento?

Ven a cumplirme, ven, tu juramento.

Scenes six, seven and eight take place in a street before the church. A soldier tells Ruiz that their forces are outside the walls; the gate is guarded, and the king has left the city, evidently suspecting an uprising. Manrique brings Leonor out from the convent; she recovers consciousness as the alarm is sounded, and the king's partisans rush out to attack Manrique's forces. The curtain falls as Manrique, defending Leonor, fights with Don Guillén and Don Nuño.

Manrique: Aquí, mis valientes.

Nuño: El es.

Guillen: Traidor.

Leonor: ¡Piedad, piedad!

Jornada Cuarta. - La Revelación.

The scene is the camp of Nuño and Guillen. The latter tells Nuño that the rebels, headed by Manrique, await them in Castellar. Guillén is blazing with desire to avenge the stain on his honor caused 
by Manrique's abduction of Leonor, who is with her lover in Castellar. As they talk, soldiers drag in Azucena. She is recognized as the abductor of Nuño's brother and is hurried off to prison exclaiming:

Ven a librarme...

$$
\text { ... Manrique, hijo, }
$$

Nuño is the more enraged to find that Manrique is a Gipsy's son.

Scene five takes place in Leonor's room in the Tower of Castellar. Leonor soliloquizes:

...Y con eternos vínculos el crimen

A su suerte me unió... Nudo funesto,

Nudo de maldición que allá en su trono

Enojado maldice un Dios terrible.

Manrique enters, much disturbed. He cannot forget his mother's story, and he has just had a dream in which he saw Leonor struck by lightning in a storm and torn from him. Ruiz enters, announcing that Nuño and Guillén are moving on Castellar, and mentioning incidentally that they have captured a Gipsy woman. Manrique, realizing his mother's peril, orders the attack. He then confesses to Leonor that the Gipsy is his mother. Her devotion remains unfailing, and she resolves to go with him:

Yo opondré mi pecho al hierro

Que tu vida amenazare;

Sí, y a falta de otro muro,

Muro será mi cadáver.

The clarion sounds, and when Manrique departs she prays

¡Gran Dios! Protege su vida,

Te lo pido por tu amor. 


\section{Jornada Quinta. - El Suplicio.}

The scene is in Saragossa, near the walls of the Aljaferia. Leonor and Ruiz have gained entrance into the city by bribing the guards. Manrique is in prison and Leonor resolves to save him at all hazards. She hears within the prison the lugubrious:

"Hagan bien para hacer bien

Por el alma de este hombre,"

but she is reassured by hearing Manrique sing:

Despacio viene la muerte

Que está sorda a mi clamor;

Para quien morir desea

Despacio viene, por Dios.

IAy! Adiós, Leonor,

Leonor.

Leonor drinks a slow poison and goes to the apartment of the Count of Luna. Nuño and Guillén have been talking together; Nuño rejoices that the troubadour is so soon to die, while Guillén is eager to find Leonor and kill ber to purge his honor. Nuno will not even await the king's approval of the death sentence on Manrique, but commands that he be beheaded immediately. When Guillén leaves, Leonor enters and finally gives Nuño her promise to be his if he will only save Manrique. She secures Nuño's permission to see Manrique, promising to tell him to forget her and to repent of his treason in championing Urgel against the king.

Scene 6 shows Azucena and the troubadour in a dark cell of the prison. Azucena says that her strength is failing; she is terrified at the thought of dying as ber mother did, and cannot drive the dreadful image from ber mind. She falls asleep thinking of her freedom in her beloved mountains. 
Leonor comes to tell Manrique he is free. He is horrified at the idea of her pleading with Nuño for him. She assures him she can never be Nuño's and urges him to flee. The poison begins to take effect, and Manrique laments his doubt of her as she bemoans the cruelty of a fate which causes her to die for the sole crime of loving him. She dies in his arms; he welcomes the thought of his coming death, and is cursing Nuño as her slayer, when Nuño, Guillén and their soldiers enter. Nuño, seeing Leonor dead and inflamed with anger at Manrique, orders him to be taken to instant execution. He compels Azucena, who now awakes, to see him beheaded. She cries:

¡Ay! ¡Esa sangre!

and exclaims to Nuño:

Sí, sí. . . luces. . . él es. . . tu hermano, imbécil!

Nuño cries:

¡Mi hermano, maldición!

and flings her violently to the floor. With the bitter exclamation

she expires.

¡Ya estás vengada!

The political events mentioned in the drama are taken from the history of Aragon in the years 1410 to 1413. An account of them is given in the Chronicle of John II for those years. ${ }^{26}$

The reader may be reminded here that when Martin I of Aragon died in 1410, there were many

20 Cf. Crónica de Juan II (por Pérez de Guzmán, B.A. E., v. 68). 
claimants to the throne, of whom the most important were the Infante Ferdinand I of Castile and the Count of Urgel. The latter supported his claims with arms; the Archbishop of Saragosa, who supported Ferdinand, was murdered at Ungel's instigation in 1411. Nine electors from the kingdom met in 1412 and declared in favor of Ferdinand, who already had troops on hand. Urgel continued to resist, but was forced to surrender in 1413. All his possessions were confiscated and he himself was imprisoned for life. Ferdinand appointed a governorgeneral to act for him.

The other events and personages of the drama are imaginary. There was at the time a certain Antón de Luna, but he fought on the side of Urgel. Garcia Gutiérrez may have chosen the name of Manrique under the influence of the career of Gob. mez Manrique (c. 1415-1490), who was a warrior fighting in the rebellion against John II and Henry IV, as well as a celebrated poet, friend of the Marquis of Santillana. As to Luna, the name was famous in Spanish history, and the most illustrious bearer of it was Don Álvaro de Luna (c. 1385-1453), favorite of John 11 and nephew of Pope Benedict XIII (Pedro de Luna). The above mentioned Gómez Manrique wrote poems satirizing a certain Don Alvaro. This is probably not Don Alvaro de Luna, ${ }^{27}$ but Garcia Gutiérrez, who no

i Cl. Fitmmaurice-Kelly, op. eit., p. 121. 
doubt read his poems, may easily have connected the two names. Gómez Manrique's friend the Marquis of Santillana was moreover a violent enemy of the same Don Álvaro de Luna.

Thus the historical background of the play is fairly accurate, but the plot is by no means even suggested by these historical events. There is a play which antedates only slightly García Gutiérrez's El trovador, and which the latter resembles considerably in general outline and even in certain minor details. This play is Larra's Macias, produced in Madrid, as we have said, in $1834 .^{28}$

The scene is laid in Andújar, the residence of the Grand Master of Calatrava, and the action takes place in the month of January, 1406.

Although Elvira loves the troubadour Macias, her hand has been promised by her father to Fernán Pérez, a protégé of the Grand Master. Elvira bemoans the absence of Macías, who had promised to return in a year to claim her. She is further distraught by a report that Macias, faithless to her, had married another. She therefore hastens her preparations for her wedding with Fernán Pérez.

Act II. The marriage ceremony is taking place, and the Grand Master is engaged in blessing the couple, when suddenly Macias appears in the rear of the hall, and demands to speak with him. The Grand Master manages to delay him until the completion of the ceremony. Though Macias has suc-

28 For the origin of the Macias-legend and its historical basis cf. H. A. Rennert, Macias o Namorado, Phlladelphia, 1900. 
ceeded in bursting in and attacking Fernán Pérez, he is thrust aside, and later set at liberty by the Grand Master.

Act III. Macias has secured permission for a duel with Fernain Perez, but he is unable to wait to see his beloved Elvira. He gains access to her house, and reproaches her for her inconstancy. She tells him she had believed him unfaithful, and is resisting his plea that she flee with him, when the Grand Master and her husband enter and seize Macias. He is thrown into prison to await the day of the duel. Fernán Pérez, who has been discovered to be a coward and a murderer, roughly refuses Elvira's request to be sent to a nunnery. She discovers that her husband intends to murder Macias in prison, and decides to warn him.

Act. IV. Macias is lamenting the loss of his beloved when suddenly she appears before him. Telling him of her husband's treacherous plans, she beseeches him to flee. He refuses to leave the prison without her, and while they talk the murderers arrive. Macias boldly attacks them, but falls mortally wounded. Elvira stabs herself and falls upon his corpse.

This play is similar in some respects to Dumas' Henri III et sa cour, which Larra mentions in the preface and which was produced in Paris Feb. 10, 1829. In its origin it is likewise a very typical Spanish Romantic play, for in addition to showing the influence of the French Romantic school, it goes back to a play of Lope de Vega, Porfiar hasta morir, which deals with the same theme. In Henri III the action is concerned with the passion of Saint-Megrin 
for the Duchess of Guise. She is bound to her husband, the Duke, as Elvira is bound to Fernán Pérez, and the plight of Macias and of Saint-Mégrin is the same. The husbands are alike cruel villains. A duel is planned between Macias and Fernán Pérez, as between Saint-Mégrin and Guise. In each case the unfortunate lover is the victim of the treachery of his lady's husband. In Henri III Saint-Mégrin refuses to leave the scene in a final interview until the Duchess confesses she loves him, and when he at least leaps out of the window, the assassins kill him. In Larra's play, Macías refuses to escape unless Elvira will go with him; his delay is fatal; Fernán Pérez's hirelings put him to death. This is also somewhat similar to the last act of Hugo's Marion de Lorme (1831).

Between Macias and El trovador there are still further points of similarity. In both, the love-motif is practically the same. Macias and Manrique are both men of tremendous passions, who find their love opposed by great obstacles and themselves confronted by powerful rivals. In each case the heroine loves a troubadour, but is about to be forced into marriage with a man of high degree. Macías and Manrique each seeks to carry off by force the object of his adoration. In Macias, Elvira hears that Macias has during his absence married another; in El trovador, Leonor learns that Manrique has been killed. In each play a duel is agreed upon between the favored lover and the more powerful rejected 
suitor. Both Elvira and Leonor prefer the convent to living with a man who is not loved. Both troubadours fall into the hands of their cruel rivals and are killed by them; the resolute efforts of Elvira and leonor to save Macias and Manrique are unavailing, and boih heroines commit suicide when their love is clearly hopeless. The corresponding personages of the two plays are similar. Macias and Manrique are both passionately in love, are both bold and skilful warriors, and are convinced that their love is more sacred than the religious or marriage vows of Leonor or Elvira. Cf. Macias, III, 4:

Macias: Ven; a ser dichosa

¿En qué parte del mundo ha de faltarncs

Un albergue, mi bien? Rompe, aniquila

Esos, que contrajiste, horribles lazos.

Los amantes son solos los esposos.

Su lazo es el amor: ¿cuál hay más santo?

with $E$ trovador, III, 5:

No, Leonor: tus votos indiscretos

No complacen a Dios; ellos le ultrajan.

Huyamos; nadie puede

Separarme de ti.

Macias is quick to reproach Elvira for supposed inconstancy. Cf. Macias, III, 4:

¡Mujer, en fin, ingrata y veleidosa!

¡Ay! ¡Infeliz del que creyó que amado

De una mujer sería eternamente!

¡Insensato! 
with El trovador, I, 4:

Demasiado te creí

Mientras tierna me halagabas

$Y$ pérfida me engañabas.

:Qué necio, qué necio fuí!

Elvira and Leonor are very much alike. Ready to give up all for their love, they are bold and resolute in their efforts to save their lovers. Both kill themselves, having made a vain sacrifice of their lives in a struggle against overwhelming fate.

Nuño and Fernán Pérez are both hard, cruel men, "noble" by birth alone. Nuño tries to have Leonor seized at the church where she is to take her vows; Fernán Pérez's passion for Elvira is like that of Nuño for Leonor, and his desire for her is equally heedless of her own inclinations. Both men are entirely unscrupulous.

Guillén, the brother of Leonor, corresponds closely with Nuño Hernández, the father of Elvira. They are much concerned with making matches which will help them politically, are much obsessed with the notion of their own "honor," and have little consideration for the wishes of the lady concerned. Both are tyrants in their households. Guillén tells Leonor to choose between marrying the man he selects for her or entering a convent. Nuño Hernández tells Elvira she shall marry Fernán Pérez or suffer his everlasting curse.

Even the minor personages of the two plays sug- 
gest each other - though here the resemblance may be conventional rather than significant. Both troubadours are accompanied by servants who are useful from the standpoint of dramatic technique as confidants, and as reporters of events which are not shown on the stage. Both Fortun and Ruiz are rather colorless figures, conspicuous only for their devotion to their masters. Beatriz, the "dueña joven de Elvira," as she is called in the "Personas," is much like Leonor's confidante Jimena, though the latter has a somewhat higher social position. They give aid and comfort to their mistresses, and are the female counterparts of Fortun and Ruiz. The soldiers of Fernán Pérez have a close parallel in the armed retainers of Nuño.

Not only is there a strong resemblance in the dramatis personae and their grouping in the two plays, but in many cases the very language of the two plays is almost identical, as is pointed out by C. A. Regensburger." Compare for example the two scenes in which the heroines are being told by their guardians that marriage with a mere troubadour is impossible and that their hands have been promised to other, unloved, candidates:

El trovador, I 2

Gunlets:

Mil quejas tengo que daros
Macias, I 4

Nus̃o Hexníndez:

$Y$ estas son tus palabras, $y$ lesto es el iruto

:Uber den Trovador dea Gareia Gutidrrez. Berlin, 191:. p. $88 \mathrm{fl}$. 


\section{First Dramatic Attempts and "EI Trovador"}

Si oírme, hermana, queréis. De un año de indulgencia y Ide esperanza...

En fin, mi palabra di

De que suya habéis de ser. Que di solemnemente, olvi-

[daria?

Poco estimáis, Leonor,

El brillo de vuestra cuna

Menospreciando al de Luna

Por un simple trovador.

... ¿ Mas qué bienes

Son los suyos, Elvira? ¿Ca-

[ballero

$Y$ no más? ¿Hombre de arImas o soldado?

¿Mal trovador, o simple

[aventurero?

En fin, ya os dije mi intento. No más rebozo ya ; tú de ese Ved cómo se ha de cumplir.

Hoy la mujer serás.

[hidalgo

The virtues of Macias are thus praised by Elvira in answer to her father's request:

\section{Nuño Herníndez:}

El mancebo

¿Quién es, y cuáles timbres, qué blasones

Le ilustran a tus ojos?

\section{Elvira:}

Pero al menos sed justo: sus virtudes, Su ingenio, su valor, sus altos hechos

No despreciẻis, señor. ¿Đónde están muchos

Que a Macías se igualen, o parezcan?

¿Su ardimiento? ¿Vos mismo no le visteis

Ha un año, poco más, en Tordesillas

Los premios del torneo arrebatando?...

¿Quién supo más bizarro en la carrera

Hacer astillas la robusta lanza? 
This is quite similar to the praise of the Count of Luna by Guillén:

¿Qué visteis, hermana, en el

Para asi tratarlo impia?

- No supera en bizarria

Al más apuesto doncel?

A caballo, en el torneo,

¿No admirasteis su pujanza?

A los botes de su lanza...

Leonor: Que cayó de un bote creo.

The ending of the second act of El trovador is much like that of the second act of Macias, even in the words used by the heroines. In Macias, as Elvira comes out of the church where she has just been married, she sees Macias, who has been absent for a year and whom she has given up. Crying "iEl es!," she swoons. In El trovador, as Leonor comes out of the church in which she has just taken her vows as a nun, she sees Manrique, who has also been absent a year and whom she had given up as dead. With the exclamation,

¿Quién es aquél? Mi deseo

Me engaña... ¡Sí, es él!

she falls fainting at Manrique's feet.

Attention seems not to have been called to this particular instance of resemblance, but further cases are cited by Regensburger (op. cit., pp. 60-63).

"Compare El trovador V 7 with Macias IV 3. Situation and dialogue are the same. 
The heroine enters the prison of the languishing troubadour:

Manrique:

¿No es ilusión?

¿Eres tú?

Yo, sí... yo soy;

A tu lado al fin estoy

Para calmar tu aflicción.

... No pierdas tiempo, por

Manrique:

Sí, tủ sola mi delirio

Puedes, hermosa, calmar.

Ven, Leonor, a consolar

Amorosa mi martirio.

Siéntate a mi lado, ven.

Las horas, infeliz, nos son

Macías:

¿Qué miro?

¿Es ella? ¿Sueño, deliro?

¿Elvira!

Elvira:

¡Tente! Habla quedo.

Oye mi voz. Ipreciosas.

Macias:

Si, Elvira, llega y habla.

i Habla y que oiga tu voz!

[Cuán deliciosa

Suena en mi oído! Un bálsa-

Imo divino

Es para el corazón.

Leonor, like Elvira, then informs the prisoner that she has made his escape possible:

\section{LEONOR:}

... En libertad estás.

... Pronto vete...

Que nos observan quizá.

Huye, vete, por Dios.
Elvira:

Sin demora

Sálvate, que a esto vengo... Los asesinos acaso aquí

Su hierro aguzan...

Urge el tiempo, parte de

The road to freedom lies open. But neither Manrique nor Macías will flee without his beloved.

MANRIQUE:

¿Sólo yo?
Macías:

¿Sin tí, bien mío?

In vain does she urge swift escape. But sudden doubt as to the faithfulness of his beloved rises in the prisoner's breast. By what means has Leonor secured his pardon? Does Elvira perhaps come to 
the prison merely through sympathy, having meanwhile given ber love to the troubadour's rival? In both cases the troubadour torments his lady with these suspicions, until he is at last convinced of the groundlessness of his apprehensions. Leonor and Elvira stand forth justified in their pure and lofty passion. Manrique and Macias burst into self-recriminations.

\section{Manksque:}

¿Y es verdad?

iY yo ingrato la olendi

Cuando muriendo por mi
Macias:

¿Necio de mi! |Qué injusta is locamente

Mi fortuna acusé! Cuando

I alevoso

Te llamo y te maldigo, itú la mis brazos

Secretamente entre peligros

iPerdón, ídolo mio!

Casting aside all false modesty, Elvira, like Leonor, at last openly expresses her love for the troubadour in the most passionate words.

LEONOR:

¿No sabes que te queria

Con todo mi corazón?
Elviru:

Si, yo también sé amar. Mul jer ninguna Amó cual te amo yo.

In both cases, however, the time for salvation has passed. The lovers all see death before their eyes.

Elvira: Primero que ser suya, entrambos juntos Muramos.

Macias: Si, muramos.

Manrique likewise goes fearlessly and resolutely 
to meet death, in accord with his words at the beginning of the scene:

$$
\begin{gathered}
\text { Manrique: ¿¿Debes tú morir también? } \\
\text { Muramos juntos los dos. }
\end{gathered}
$$

Then comes the catastrophe, in the presentation of which the dramas are not completely similar (cf. Macias IV 3, 4 and El trovador V 7,8); the situation is, however, the same: both lovers perish in prison before the eyes of their rivals. Pointing to Elvira, the dying Macias cries out triumphantly to his enemy:

... Es mia

Para siempre. . sí. . arráncamela ahora, tirano.

Manrique similarly answers Don Nuño's question: Nuño:

¿Dónde está Leonor?

\section{Manrique: ¿Dónde? Aquí estaba}

¿Venís a arrebatármela en la tumba?

After what has been said, there is no doubt that the main plot of El trovador, the story of the illstarred love between Manrique and Leonor, is patterned directly on the Macias tragedy. But even in style and diction, numerous agreements are discernible. They are especially evident in the passionate outcries and lamentations of the hero himself.

Compare El trovador V 7:

Clava en mi pecho un puñal

Antes que verte perjura

Llena de amor y ternura

En los brazos de un rival. 
with Macias II 9:

Clávame antes en el pecho

Un puñal que eso me digas.

Further: El trovador V 7:

¿La vida! ¿Es algo la vida?

¿Un doble martirio! iUn yugo!

with Macias III 5:

¿Qué es la vida?

Un tormento insufrible, si a tu lado

No he de pasarla ya!"

Even the accessories for beightening the effect in the prison scene in Macias - the torches of the approaching retainers - have been taken over by Garcia Gutiérrez. The soldiers appear "con luces" (El trovacior V 8) and Don Nuño cries, pointing to Manrique's corpse,

iAlumbrad a la victima, alumbradla!

whereas Elvira dies with the words (Macias IV 4)

Llegad; $\mathrm{y}$;que estas bodas alumbren Vuestras teas funerales!

In El trovador, then, we have a play based on Macias, which in turn was a development of Lope de Vega's Porfiar hasta morir worked over according to the Romantic formula, as especially exemplified in Dumas' Henri III et sa cour. But Garcia Gutiérrez was not content to follow his model quite so closely as the preceding paragraphs might lead 
one to suppose; for he added a very important element by creating the rôle of Azucena and all which that entailed. In so doing he added to the theme of unhappy love the theme of vengeance.

"One of these two elements," says Piñeyro (op. cit., p. 98), "would have been sufficient for the construction of an interesting drama in the manner of Lope de Vega or Calderón. The poet, seeking something more, creates then the tragic figure of Azucena, the Gipsy, who for years and years has been preparing her frightful revenge; he thus makes his poem grander, and constructs from it with a widened horizon a vast picture of violent passions, of love and hate..."

The theme of vengeance as a moving force is as old as the drama itself. There were conspicuous examples of it in the French and Spanish Romantic theatres prior to the year 1836. For instance, in Dumas' Henri III et sa cour, it is the vengeance of the Duke of Guise on Saint-Mégrin which motivates the denoûment. This play was produced in 1829. In Victor Hugo's Marie Tudor (1833) much of the action is concerned with Gilbert's vengeance on Fabiani, who has insulted him and seduced his sweetheart Jane. Dumas' Catherine Howard (1834) furnishes an excellent example of the treatment of vengeance by a melodramatic Romanticist. Ethelwood, secretly married to Catherine, is finally betrayed by her in favor of King Henry VIII. Catherine proves to be by no means like Caesar's 
wife, and Henry has her sentenced to death. She appeals to the Judgment of God against the sentence of the Court of the Star Chamber; Ethelwood defeats her champion. She bribes the executioner to desert his duties and to leave the city, but King Henry offers a reward of twenty pounds to anyone who will volunteer to perform the executioner's duties. This is the sort of opportunity for which Ethelwood has been waiting. He strikes off Catherine's head and, unmasking, cries "...j'ai frappe la coupable; voici le complice." In the Don Alvaro of the Duke of Rivas, the brothers of Leonor spend their lives trying to avenge their father's death and their sister's disgrace. Her older brother is killed in Italy in a duel with Don Alvaro; her second brother, Don Alfonso, finally discovers Don Alvaro in the monastery and is fatally wounded by him. Leonor rushes up and her brother, seizing his dagger with his last convulsive strength, stabs her, with the words, "Toma, causa de tantos desastres, recibe el precio de tu deshonra... Muero vengado."

With these recent examples in mind, it seems not unnatural that Garcia Gutiérrez should have included the theme of vengeance in El trovador, as be did in some of his later works. Nor was it strange that he should have chosen a Gipsy to embody it. Gipsies were, and still are, a familiar sight in Spain, and especially in Garcia Gutiérrez's native Andalusia. He must have heard in his youth many tales of children kidnapped by Gipsies; Spanish 
literature had also been familiar with them from the earliest times. The Libro de Apolonio ${ }^{30}$ (early thirteenth century) contained the story which was the prototype of the numerous Gipsy stories, from Cervantes' La Gitanilla (1632) to Victor Hugo's Notre-Dame de Paris (1831). The Medora of Lope de Rueda (c. 1510-1565) deals with a child stolen by Gipsies, and this play is based on an earlier one called La Zingana (1545) by Gigio Artemio Giancarli. $^{31}$ In the same year in which Garcia Gutiérrez wrote $E l$ trovador, he translated the play of Scribe which tells the story of the daughter of an English nobleman whose identity is discovered after she has been held by Gipsies for many years. This play was La Bohemienne, already outlined in this chapter. It is possible, too, that Garcia Gutiérrez may have known the play of Ducange and Frédéric called La sorcière, ou l'orphelin écossais. ${ }^{32}$ This piece, based on Scott's Guy Mannering, was produced in 1821, and deals with the career of Lord Bertram's son Arthur, who was stolen in his youth by the Gipsy Meg Merillies.

In the preceding instances the children in question were recognized in time to make a happy dénoûment. Such an ending was impossible in El trovador. Its conclusion reminds us strongly of the last act of

\footnotetext{
so Cf. Fitzmaurice-Kelly, op. cit., p. 290.

a Cf. Ticknor, Hist. of Span Lit., New York, 1854, Vol. II. Chap. VII.

:2 In Théatre contemporain illustré, Paris, Lévy Frères, s. d.
} 
Dumas' La Tour de Nesle (1832), which Garcia Gutierrez afterwards translated under the title of Margarila de Borgoña (see page 106). We have here a mother, Marguerite de Bourgogne, who brings about the death of her two sons, discovering their identity shortly afterwards. Buridan, their father, and Marguerite burst into the locked room of the Tower of Nesle in time to see their son Gaultier d'Aulnay die at the hands of the assassin whom Marguerite has hired (Act V, sc. 4). She cries "Malheureux, malheureux, je suis ta mere!" He replies with his dying breath, "Ma mère? Eh bien, ma mère, soyez maudite!" We have much the same sort of melodramatic situation at the end of El trovador, when Azucena cries to Don Nuño: "Él es tu her. mano, imbécil," and he replies " iMi hermano! ¿Maldición!" In Pacheco's Alfredo, we have the murder of a father by his son, and in Martinez de la Rosa's Conjuracion de Venecia a father presides over the tribunal which passes the death sentence upon his son. The trick of having parents kill their children and vice versa, and brother murder brother without knowing each other's identity was very popular at the time, and we shall see Garcia Gutiérrez relying upon it again in his next play.

In minor matters of technique Garcia Gutiérrez often follows his immediate French predecessors. For example, be has a title for each one of his five acts, or 'jornadas,' as he calls them for the sake of giving them an archaic flavor. Such titles had 
not been used in the Spanish theatre, but had come into favor in France with Hernani (1830), and were promptly used by Dumas, as in La Tour de Nesle. They were not used by Larra, Martinez de la Rosa or Hartzenbusch, but had been employed by Pacheco in Alfredo. The division of El trovador into five acts was likewise due to French influence, for the Spanish classic theatre used three. The pseudo-classic Eighteenth Century used five as a rule, following the French formula, as did La conjuración de Venecia, Don Alvaro and Alfredo. Larra's Macias is divided into only four acts. In the use of both prose and verse in El trovador, Garcia Gutiérrez broke with both French and Spanish tradition. The first Spanish Romanticist to do this was the Duke of Rivas in his Don Alvaro. The Duke spent much of his political exile in Malta with the cultured Englishman Jofn Hookham Frere, and very probably read Shakespeare in Frere's library. Later, in Paris, he must certainly have read him under the influence of enthusiasts like Hugo, who in his preface to Cromwell declares Shakespeare to be the epitome of the drama of the Modern Era. It seems therefore quite possible that the use of a mixture of prose and verse goes back to the great English dramatist. The French Romantic plays were written either entirely in verse or entirely in prose. In Don Alvaro prose is employed in scenes in which the main participants are of minor social importance, as in the exposition scene (Act I, sc. 1). The same 
plan is followed in the main by Garcia Gutierrez, though in scene 7 of Act III the participants are Leonor and Manrique. Prose is used in Act I, sc. 1, in the conversation of the servants Guzman, Jimeno. and Ferrando; in all except the first speech in Act II, sc. 2, between Don Nuño and Guzmán, and in scenes 3,4 and 5 of the same Act, with Don Nuno, Don Lope and Guzmín; in Act III, scenes 1, 2 and 3, giving the conversation between Azucena and Manrique; in sc. 6, between Ruiz and a soldier; sc. 7, between Leonor and Manrique, and sc. 8 (only eight words long), depicting the fight between the adherents of Don Nuño and those of Manrique; and in sc. 6 of Act V, between Azucena and Manrique. The last eight lines of this scene, recited by Manrique after Azucena has fallen asleep, are in verse. Approximately one fourth of the play is in prose - about the same proportion, incidentally, as in Hamlet.

The first scene of El trovador is used solely for the exposition of the plot. We have three servants talking together of dark and mysterious events, including the disappearance of a child who is later to be the hero of the drama. This scene is strikingly like the first scene of Victor Hugo's Lucrèce Borgia (1833). In both cases the oldest servant relates the story to two younger ones, who punctuate the account with expressions of astonishment or approval. In Lucrèce Borgia, Jeppo begins: "Moi, je sais les faits, messeigneurs, je les tiens de mon cousin... 
Voici, c'est quatorze cent quatre-vingt-dix-sept..." In El trovador, Jimeno says: "Nadie mejor que yo puede saber esa historia... Ya os la contaré como ello pasó por los años de 1390." Similar exposition scenes were used by Dumas in La Tour de Nesle and by the Duke of Rivas in Don Alvaro, though in these two plays the protagonists themselves appear during the scene, and the dramatic machinery is therefore a little less conspicuous. Moreover, the comic element is present in the plays of Dumas, Hugo and the Duke of Rivas, both in these earliest scenes and elsewhere; in El torvador it is entirely lacking.

In his story Jimeno mentions the night interview in which Leonor mistook Don Nuño for her lover and was much frightened to discover her mistake; Manrique is near by and disarms Don Nuño. This is quite similar to Hernani, Act II, sc. 2, in which Doña Sol mistakes Don Carlos for Hernani in the darkness; Hernani comes up and drives off the king. ${ }^{33}$

In Don Alvaro, the heroine Leonor takes refuge in a convent, where Don Álvaro at last finds her. This may possibly have suggested the idea of a convent scene to García Gutiérrez, but the statement of Regensburger (op. cit., p. 78) that the "convent theme comes directly from Don Álvaro" can hardly be accepted. The convent was the na-

s C. Regensburker, op. cit., p. 78 . 
tural refuge of young women in the Middle Ages, and its employment under the circumstances seems rather an obvious solution of the difficulty. The abduction of Leonor from the convent and the escape of the lovers to Castellar were Garcia Gutierrez's own invention, and his debt to the Duke of Rivas' play in this respect is small indeed.

The circumstances in Act $V$ of $E d$ trovador are somewhat similar to those in the last act of Hugo's Marion de Lorme. In the latter play Marion, finding all other plans of no avail, surrenders herself to the jailer Laffemas so as to win the release of Didier; in El trovador Leonor promises Don Nuño to be his if he will free Manrique. Didier will have no delivrance bought at this price; Manrique likewise says (Act V, sc. 7):

No quiero la libertad

A tanta costa comprada.

But the circumstances are very different, in that Marion had really paid the price to Laffemas, and had hoped that she and Didier might be free to go forth together, whereas Leonor had merely given Nuño an empty promise and nothing more, having taken poison before talking with him.

We have endeavored in the preceding paragraphs to show the general influences affecting Garcia Gutiérrez when he composed El trovador, and to itemize the particular points in which he was indebted to his predecessors. We by no means wish 
to leave the impression, however, that the drama is a mere synthesis of parts borrowed from other authors and consequently quite lacking in originality, for such is not the case. It is obvious from a mere cursory reading of El trovador that it is cast in the Romantic mould, with many similarities to the works of French Romantic dramatists; and from closer study it is evident that certain scenes, even certain sentences are quite similar to the corresponding parts of other dramas which García Gutiérrez knew and admired. Yet the play as a whole remains an original dramatic creation. We have seen that the piece which it most resembles in general plan and in many particulars is Larra's Macias. Larra himself was the foremost dramatic critic of the day, and if he had thought El trovador a mere copy of his own play, produced the preceding year, it would have been easy and natural for him to say so; on the contrary, he devoted a rather long article to the criticism of El trovador ${ }^{34}$ he bestows high praise upon the new star among dramatic authors; he commends him for his well conceived plan, the skillful development of the plot, and its satisfactory dénoûment, and states that its faults are due merely to the author's lack of dramatic experience. The originality of the play consists in the happy combination of the motifs of love and hate, intertwining the two until they reach a catastrophe which 80-83.

\& Cl. Obras de Figaro, Paris, Baudry, 1857, vol. II, pp. 
is a logical solution of both. The vigor of the scenes, the skilful condensation of the action, and the lyric beauty of much of the verse are all Garcia Gutierrez's own creation, and are enough to give him, as they have done, a very important place among Spain's dramatists of the Romantic era.

The character of Leonor is finely drawn, and is made more interesting and convincing by the conflict waged in her soul between her love for Manrique and her duty to remain faithful to her vows as a nun. We feel sure that her love will triumph, for she had already shown her brother Don sume that she recognized no human right to force her affections or control her hand; she refuses absolutely to be a sacrifice to his ambition, and that in no uncertain terms, for in the first scene in which she appears (Act I, sc. 2), she defies her brother:

Que nunca seré del conde...

Nunca. ¿Lo ois, don Guillén?

Her will can be bent only by one who loves her and whom she loves. For him she is capable of entire self-abnegation, as shown by her words in Act I, sc. 3:

...Ven, trovador, y mi lloro

Te dirá cómo te adoro,

$Y$ mi angustia te dirá.

Mírame aqui prosternada;

Ven a calmar la inquietud

De esta mujer desdichada;

Tuyo es mi amor, mi virtud. .

¿Me quieres más humillada? 
When Manrique suspects her of unfaithfulness, she has no indignation toward him, only sorrow at his suspicions. When he says:

No vengo lleno de amor

Cual un tiempo...

she replies simply:

\section{¡Desdichada!}

and patiently explains how she mistook the Count for him in the darkness of the garden. Her love is - by no means merely passive; for Manrique she will desert the convent - where she has never been able to drive him from her mind - and when he is imprisoned she does her utmost to bring about his deliverance. When at last she sees the hopelessness of struggling against fate, she even humbles herself to the Count. There can be no more happiness for her; she takes poison, not caring for her fate, if only she may liberate her beloved troubadour.

The character of Manrique is painted with less delicate strokes. He loves Leonor, but his love is not at all one which trusts and can remain unshaken under all circumstances. In his supposed disillusionment in Act I, sc. 4, he is bitter toward Leonor. When she says, at his coming:

$$
\text { ¿No ves? Lloro de placer. }
$$

he replies:

¿Quién, perjura, te creyera?

But his chagrin was caused by his love for her, for 
he confesses, after her explanation, that he could never risk death in Saragossa, the citadel of his enemies, except for ber. He then continues:

$\mathrm{Ni}$ asi pudiera vivir;

$$
\text { ... No, ya no dudo }
$$

Me amas, ¿es verdad? Lo creo

Porque creerte deseo

Para amarte y existir.

Porque me fuera la muerte

Más grata que tu desdén.

Toward others be is proud and haughty, as toward Don Nuño. With his supposed mother, be is at times loving and tender, at times forgetful, as when (Act III, sc. 2) he goes off with Ruiz without even bidding her farewell. Heroic always, be even longs for death after Leonor can no longer be his.

The sinister figure of Azucena, entirely an original creation, is probably the most interesting in the play, though she does not come upon the stage until Act III. Her very first lines, the song beginning:

Bramando está el pueblo indómito

De la hoguera en derredor,

strike the keynote of her passion for vengeance. She is irresistibly drawn toward the spot where ber mother was burned; the idea of completing ber revenge never leaves her until her last bitter cry "; $\mathrm{Ya}_{2}$ estás vengada!" She desires Manrique's affection, however, and she wishes him to shield her in ber old age, as she says in her soliloquy in Act III, sc. 3. In Act IV, sc. 6, she tells Manrique that she loves 
him as her own life, and has prayed for him the whole night through. She dreams of fleeing with him to her native mountains, but all the while she knows that a word from her can save him from the hands of Don Nuño, a word which she witholds until it is too late.

The greatest defect in the play is the poorly accounted-for burning of her own son by Azucena. Audiences might and do pardon the strange dispensations of chance in this and other Romantic plays, but Azucena's explanation that her hand reached out convulsively for a victim and seized her own son, throwing him in the fire without even looking at him, seems to overstrain even the most complete credulity. It adds very little to the play; the disappearance of Azucena's own son could easily have been accounted for in some other way. Piñeyro says (op. cit., p. 101): "I have known persons (not of Spanish origin and unacquainted with the Spanish text) who have heard Verdi's opera $I l$ Trovatore several times without getting a clear idea of the meaning of this scene."

Larra (op. cit.) has pointed out other defects of the drama, which, says he, all spring from the author's inexperience. "He has imagined a vast plot, the plot of a novel rather than of a drama, and he has invented a magnificent novel, but in reducing an over-rich conception to the narrow limits of the theatre, he has had to struggle with the smallness of his mould. 
"The result is that many entrances and exits are scarcely justified; among them the entrance of the outlaw Manrique into Saragossa and into the palace, in the first act; his entry into the convent in the second act, his introduction into Leonor's cell in the third, a thing too difficult in all periods not to deserve an explanation. Neither is it natural that the Count Don Nuño, who must be very distrustful of the tardy promises of a woman who has preferred the convent to his hand, should allow her to go to the troubadour's prison, the more so since she has not even any order from him to set him at liberty, without which the concession which she has won from him cannot suffice, cannot even do any good." Larra also objects to the first scene of the drama, which, he says, is rather a prologue in prose than a scene of the play. He disapproves moreover of the mixture of prose and verse.

It is quite fair to point out the defects of the play as judged by contemporary standards; in this case the faults which Iarra has pointed out are also apparent to those who view the Romantic era in retrospect. Other defects which we observe must not be imputed to Garcia Gutierrez alone, but to the Romanticists in general. The passions of the protagonists, Leonor, Manrique and Azucena, may seem to us exaggerated; but the portrayal of the passions of the individual was one of the chief tenets of the Romantic school. The passions of these three are by no means more exaggerated than is the case 
in the dramas of Hugo, and they are much more universally human than in the plays of the elder Dumas. The dispensations of a blind fate which drives men and women to love, and makes their love lure them to their destruction, is quite in accordance with the Romantic formula. The contest rages about Leonor, who becomes its innocent sacrifice.

The author's lack of stage experience may have led him into errors, but the vigorous movement of the whole play and the numerous excellent theatrical effects show him as possessed of a powerful dramatic instinct. No time is wasted in useless dialogue or soliloquy, and the interest of the spectator is well sustained from beginning to end. The play is quite concise, more so than many of the author's later works. Even in the first scene, which is a mere story, the narration is rapid and is made to seem natural by the remarks of the listeners. The final words are worth quoting as a specimen of simple and vivid narrative.

Guzmán: "His (Don Nuño's) intention was to enter Leonor's room, for which purpose he had provided himself with a key.

Jimeno: What? In the palace! He really dared to?

Guzmán: He actually entered; but at the very moment when, full of love and expectancy, he thought to realize his supreme happiness, a prelude from the lute of the accursed troubadour sounded to awaken him from his delirium. 
Ferrando: The troubadour!

Guzmán: He himself; he was in the garden. 'There,' said Don Nuño in dreadful tones, 'she must be also.' And, raging, he descended the stair. The night was very dark; the singer, who never struck his lute more inopportunely, withdrew, doubtless believing that my master was some curious squire; in a little while the virtuous Leonor came down, and, mistaking my master for her lover, led him silently to the most secluded part of the garden. Very quickly the daring words of the Count made her realize with whom she was conversing; the moon, until then prudently covered with a very dense cloud, made the jealous singer's steel gleam at my master's breast; the fight was short; the Count's sword fell at his rival's feet, and a moment later there was not a soul in all the garden."

The endings of the acts are excellent. Act I closes with the departure of Manrique and Don Nuño for the duelling ground. Each of the acts follows this general plan, completing its own episode in the drama but leaving the spectator anxious to see what is to follow. Acts II and III end in much excitement, and are melodramatic in effect, but they are well conceived to create further interest. In Act II. sc. 8 , just as the Count's servants are about to seize Leonor in the church, they see the troubadour, and flee; as Leonor passes him, Manrique lifts his visor. She, who had also thought him dead, falls fainting at his feet. It is not until scene 4 of the next act 
that we see Leonor again and find that she has really entered the convent, where, however, she cannot forget Manrique.

Act III ends with the flight of Leonor and Manrique. Nuño and Guillén pursue them; Leonor distinguishes their standards in the distance. Finally they approach; the curtain falls as Manrique, defending Leonor, cuts a path for them through the ranks of his enemies. The effect is heightened by the torches of the soldiers and the ringing of the alarm bell in Saragossa.

The fourth act ends more calmly, but also with suppressed excitement. The clarion calls as Manrique is bidding farewell to Leonor; he departs, and as she is lamenting his going, the clarion sounds again. She closes the act with the words

¡Gran Dios! Protege su vida, Te lo pido por tu amor.

The last scene (sc. 9) of the last act is pure melodrama. The catastrophe is blood-curdling enough to be worthy of the elder Dumas. Leonor dies of poison; Azucena, deciding too late that she cannot sacrifice Manrique to avenge her mother, is forced to see him beheaded; she screams, and informs Nuño of his relationship to the dead troubadour, and after his curse:

¡Mi hermano, maldición!

she cries bitterly:

¡Ya estás vengada! 
and dies. There is nothing to soften the violence of the scene except that Manrique's execution does not take place on the stage. The scene, with all its violence, has the merit of brevity; the agony is not prolonged and the whole is decidedly effective.

The most happily conceived and felicitously expressed scenes in the whole play are scenes six, seven and eight of the second act. The author gives careful directions for the stage setting:

"At the back of the stage there will be seen the grating of the reception room in a convent; three doors, one beside the grating, which connects with the interior of the convent; another on the right, which leads to the church, and the third on the left, which is supposed to be the street entrance.

"Nuns are seen in the reception room; the door beside the grating opens, and Leonor appears, leaning on the arm of Jimena; a few monks and nuns accompany them."

Then Leonor bids farewell to Jimena, confessing that she is about to make a false vow, for the troubadour still fills her thoughts. All go into the church; Manrique and Ruiz enter; Manrique shows his understanding of Leonor's action; a false report of his death had been spread and he perceives she had resolved to take the veil so as to escape the persecution of her brother and the Count. Ruiz goes out, and Nuño's servants, sent to seize Leonor, enter. The chanting of the choir is heard as the procession crosses from the church to the convent, and the chant continues throughout the scene (now 
known as the "Miserere scene"). The act ends as described above with the recognition of Manrique by Leonor, her swooning at his feet, and the flight of Nuño's servants.

These scenes could hardly be improved upon. They are short, contain nothing superfluous, are extremely moving, and gain a dignity and solemnity from their religious surroundings and from the offstage chanting. They have remained, and justly, the most popular portion of García Gutiérrez's most popular drama.

It has often been pointed out that there has seldom been a drama which could so easily be turned into an opera; Piñeyro says (op. cit., p. 101) "One might say that Garcia Gutiérrez wrote his poem foreseeing that it would be set to music, and facilitating beforehand the task of the composer." The libretto of $l l$ Trowatore was written in 1851 by Salvatore Cammarano. Verdi began work on the score in the same year, but the opera did not attain production until the first part of 1853. The first scene of the third act of El trovador is opened with a song, that of Azucena. Manrique announces his coming in scene 4 of the same act with the singing of a ballad. The whole piece, in which passion plays a predominant part, is especially well adapted to musical expression.

The variety of metre in $\mathrm{El}$ trovador is greater than in the theatre of the Golden Age, which in turn was far greater than in the French Classic theatre. But 
this freedom was not original with Garcia Gutiérrez, for the Duke of Rivas' Don Alvaro, also written partly in prose and partly in verse, was fully as free in the matter of versification. The author of El trovador is much the better technician, for the verse of his play is uniformly well constructed and mellifluous, while that of Don Alvaro is uneven, at times decidedly lame.

Indeed, the peculiar merit of Garcia Gutiérrez consists precisely in his ability as a dramatic poet. In all the metres which he employs he seems thoroughly at home; no effort is apparent, and his verse seems a natural and harmonious expression of his ideas. It is elegant in its simplicity, a model of felicity. Ir. narrative passages it is vigorous and moves rapidly; in lyric passages, of which the play is full, it is tender, delicate, moving, free from exaggerated sentimentality. It is always direct; the desired emotion is never buried beneath obscure figures of speech.

Take for example the lament of Leonor in scene 3 of the first act:

Llorando, si;

Yo para llorar naci;

Mi negra estrella enemiga,

Mi suerte lo quiere asi.

Despreciada, aborrecida

Del que amante idolatré ¿Qué es ya para mí la vida? 


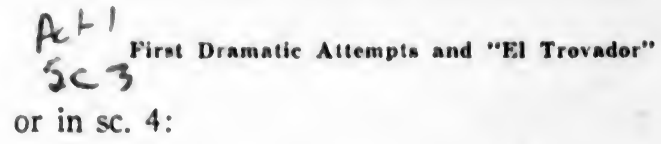

or in sc. 4 :

Si, pero juzgué engañada

Que eras tú; con voz pausada

Cantar una trova oí.

Era tu voz, tu laúd;

Era el canto seductor

De un amante trovador,

Lleno de tierna inquietud.

Turbada, perdi mi calma,

Se estremeció el corazón,

$Y$ una celeste ilusión

Me abrasó de amor el alma.

About such verse there hovers a youthful vigor and freshness which enhances the emotions expressed. It is excellent art because this emotion is conveyed to us directly and we are scarcely conscious of the medium by which it is expressed. Further excellent eaxmples are offered by Act II, sc. 6; Act III, sc. 4 and 5 ; Act IV, sc. 6 and 9.

Probably the most pathetic passage of the drama is the lament of Manrique over the death of Leonor (Act V, sc. 7):

A morir dispuesto estoy...

Mas no; esperad un instante;

A contemplar su semblante,

A adorarla otra vez voy.

Aqui está. Dadme el laúd;

En trova triste y llorosa,

En endecha lastimosa

Os contaré su virtud.

Una corona de flores

Dadme también; en su frente 
Será aureola luciente,

Será diadema de amores.

Dadma, vereisla brillar

En su frente hermosa y pura;

Mas llorad su desventura

Como a mi me veis llorar.

Qué funesto resplandor!

¿Tan pronto vienen por mi?

El verdugo es aquél... Sí

Tiene el rostro de traidor.

Manrique's emotion is thus made to seem sincere, poignant, a real expression of feeling rather than a declamatory outburst. The pasage is short, and does not interfere with the rapidity of the action, merely lending it a dignity and an emotional background which heightens the effect.

High piaise is bestowed on the author by the com. petent Cuban critic, Enrique Piñeyro (op. cit., p. 102):

"Garcia Gutiérrez's precious gift. . . is his gift for versification, which is constantly facile, sweet, melodious. The union of this gift with the natural melancholy of his character and the instinctive sadness of his poetry made him naturally the most moving, the most affecting, the most pathetic of the modern dramatic poets of Spain. It is quite possible that at no time has there existed anyone in the literature of Spain who deserves to be compared with him in this regard." 



\section{CHAPTER IV.}

\section{Romantic Plays Subequent to El. Trovador.}

Since E.t trovador won such laurels, it was but natural that its author should seek further success along similar lines. His next play was entitled $E d$ paje. We have endeavored to point out the influences operative upon Garcia Gutiérrez in writing El tro. vador; the same influences remained potent when he wrote $E l$ paje and the other plays of the seven years up to and including Simón Bocanegra, the author's next outstanding success.

El paje was represented in Madrid at the Teatro del Principe on May 22, 1837, slightly more than a year after $\mathrm{El}$ trovador. It is in four acts, as are the Macias (1835) of Iarra and Los amantes de Teruel (1837) of Hartzenbusch. The Duke of Rivas' Don Alvaro (1835) and Martínez de la Rosa's La conjuración de Venecia (1834), as well as Garcia Gutiérrez's El trovador (1836) each had five acts, the number regularly used by Hugo and Dumas. The unities of time and place are disregarded, 
for the action is supposed to begin March 20, 1369 and to continue for several days, and the scene changes from Cordova to Seville.

The page who is the protagonist is a boy of fifteen named Ferrando. Despite his tender age he is high-spirited to the last degree; when we first see him he is quarreling at cards with a much older man and is about to challenge him to a duel, when his wrath is assuaged by Leonor, the sister of Doña Blanca. Blanca, whom Ferrando serves as page, is the wife of the elderly and proud Don Martin de Sandoval. Ferrando confesses to Leonor that he is deeply in love; the object of his passion is even fairer and better than Leonor, for Leonor, he admits, is only an angel, while his beloved is a goddess.

When Ferrando makes his exit, Blanca enters and talks with Leonor. From their conversation we learn that in days gone by Blanca had had a lover, Rodrigo, to whom she had borne a son fifteen years ago and had shortly afterward been forced to part with both lover and child. She has recently seen Rodrigo and fears he may cause her trouble. Rodrigo is not long in making his appearance; he still loves Blanca and wishes her to flee with him. She tries to remain faithful to her husband Martin and bids Rodrigo leave her. He says:

Rodrigo: ¿`Vos lo queréis? Adiós, señora; ¿Adiós eternamente! Y si a tu oído

Llega mi muerte, por mi muerte llora.

He does not quite mean it, however, for he pauses on the threshold to ask her if there is really nothing which she would like to ask him. Overcome with emotion, she enquires about their child and finally confesses her love for Rodrigo. The latter states 
that he has lost trace of the child, whom he was forced to abandon years ago and whom he had entrusted to a fisherman in Seville, leaving with him a sword as a means of identification.

Enter don Martin, to whom Rodrigo explains his presence by offering letters supposedly from Martín's brother. But Martin's old servant Bermudo recognizes Rodrigo as Blanca's lover and informs Martin of their former relations.

In the second act leonor goes to Rodrigo's inn with a letter from Blanca urging him not to try to see her again. As he is preparing to disobey her, Bermudo enters and, pretending to wish to further Rodrigo's plans, gives him the key to Blanca's oratory, where she is always to be found at the hour of evening prayer.

At vesper time Ferrando is pouring forth his hopeless love for Blanca in a passionate lay when Rodrigo enters the oratory. Rodrigo and Blanca are immediately betrayed to Martin by Bermudo.

Bermudo:

Doña Blanca:

Don Martin:

Don Rodrigo: iPidela a Dios para ti!

Act III opens with a chance encounter between Rodrigo and Nuño, the fisherman to whom he had entrusted his son. Nuño had been forced to abandon him thirteen years before, but left with him the sword by means of which he even now thinks he may be able to discover him.

Ferrando receives a mysterious letter from the man he had always regarded as his father, informing him that he is a foundling.

Martin is lying ill from wounds inflicted on him by Rodrigo. Blanca is preparing to fly with Ro- 
drigo to Seville. Ferrando finally musters up sufficient courage to declare to Blanca his love for her. She encourages him and bids him show his love by murdering Martín. He hesitates, but finally consents. Martin's death-cry is heard; Ferrando comes out in time to see Blanca flee with Rodrigo.

In the fourth act Nuño finds Ferrando, recognizes the sword which he wears and informs him that he is Rodrigo's son. Ferrando therefore resolves to rid his father of so treacherous and wicked a woman as Blanca, and makes his way to the house which they are to occupy in Seville. Hiding in their bedroom, he awaits Blanca and upon her arrival accuses her of her crimes, bidding her prepare to die. On his proclaiming himself the son of Rodrigo, she cries that she is his mother; but too late, for Ferrando has already swallowed a slow poison which now begins to take effect. Just before his death, Rodrigo enters; he condemns Blanca as the cause of the tragedy and declares that they can never be happy together. His final words are:

Tú una maldición pusiste

$Y$ una tumba entre los dos.

This play is constructed so completely on the plan of the French Romanticists that we shall find it convenient to discuss it in connection with a play of the elder Dumas which it resembles more than superficially and which was translated by Garcia Gutiérrez for the Spanish stage in 1836. This play is La Tour de Nesle (called in Spanish Margarita de Borgoña) and was first represented at the Porte Saint-Martin in 1832. It is in five acts and in prose; the action is placed in Paris in 1314. Larra wrote 
a condemnatory review of the play just after its first presentation in Madrid."s

Act I. Philippe d'Aulnay. - Tableau I. Philippe d'Aulnay is writing in a tavern kept by the Italian Orsini. Philippe is a young soldier just arrived from Flanders who hopes to win preferment at court through the influence of his brother Gaultier, the favorite of Marguerite of Burgundy. A crowd of the habitues of the tavern begin in loud voices to revile Gaultier, and Philippe is quick to draw his sword against all ten of them. He is hard pressed. Buridan, a captain recently arrived from Italy, chances to enter the tavern and comes to his aid. The ruffians are quickly routed. Philippe and Buridan fall to talking of recent occurrences in Paris. Rumors are afloat of strange happenings near the Tour de Nesle; every morning dead men have been found in the Seine below the tower. Philippe informs Buridan that he has a rendez-vous for the evening; an old woman gave him a ring and told him to be at the corner of the rue Froid-Mantel at curfew; from there he would be conducted into the presence of a most beautiful and charming young woman. While Philippe and Buridan are still talking the old woman brings Buridan a ring with the same message. They decide to keep the appointment together.

Gaultier d'Aulnay arrives and greets his brother affectionately. Upon hearing of the strange rendezvous, he strongly urges Philippe and Buridan not to keep it. Philippe agrees to meet his brother in the morning.

Tableau II. (At the Tour de Nesle. The same

"See Larra, Obres, Caracas. 1839. vol. II. pp. $97 \mathrm{R}$. 
night.) Orsini, who is really in the employ of Marguerite of Burgundy, soliloquizes on the beauty of the night for love. Marguerite enters and talks with him about her gallant for the night. The young man, says she, is so much like Gaultier d'Aulnay that she wishes his life to be spared, for she has not unmasked and there is no danger of her being recognized.

As Orsini departs, Philippe enters and makes ardent love to Marguerite. When she bids him go and refuses to unmask or to reveal her identity, he scratches the skin under her mask with a golden pin. Enraged, she goes off to countermand her order to Orsini.

Buridan appears and tells Philippe he is sure their entertainers are of high lineage and that the affair bodes ill, for he realizes that they are in the dreadful Tour de Nesle. They then agree that if either survives he will avenge the other's death. Philippe draws blood with the golden pin, writes "I was assassinated by ....," signs and gives the paper to Buridan. As Buridan endeavors to make his way out of the tower, he is accosted by a man named Landry, who bids him say his prayers. Buridan recognizes Landry, who had served under him in Italy; Landry therefore spares him and shows him a secret window over the Seine. Buridan shouts and plunges into the river. Philippe is stabbed; before dying he staggers into Marguerite's presence and recognizes her. The act closes with the night-crier's words, "Ill est trois heures. Tout est tranquille. Parisiens, dormez."

Act II. Marguerite de Bourgogne. - Tableau III. Gaultier d'Aulnay sees Marguerite in the morning and laments the fact that the coming of the king 
on the morrow will separate them forever. While various courtiers discuss the discontent aroused by the finding of the bodies of so many young nobles near the Tour de Nesle, a Gipsy enters the court and prophesies the death of the present Prime Min. ister. Talking with Marguerite alone, he reveals knowledge of the doings of the night before, tells her of Philippe's death and shows her the golden pin. He thereby frightens her into promising him an interview at curfew in Orsini's tavern. Gaultier d'Aulnay swears to avenge his brother's death.

Tableau IV. Philippe's last mesage, declaring Marguerite to be his murderer, has been sent by Buridan to Gauitier d'Aulnay, who has promised not to open it until the morrow and to return it unopened if Buridan sends for it before then. Buridan sees Marguerite at Orsini's tavern, tells her he was the Gipsy who came to her court that morning and shows her that he knows her secrets. Realizing her genuine love for Gaultier, he swears to let him open the paper proving her guilty of Philippe's death unless she orders the immediate arrest of the Prime Minister, Enquerrand de Marigny, and puts Buridan in his place. After Buridan departs with her promise, Gaultier happens to come to the tavern, and Marguerite finally persuades him to give her the mysterivus paper which he has received. She tears out her name and gives it back to him.

Act III. Enquerrand de Marigny. - Tableau V. The Prime Minister Enquerrand de Marigny is arrested through Buridan's machinations. Marguerite also has Buridan apprehended and thrown into the Grand Chåtelet.

Tableau VI. Buridan's jailor is his former soldier Landry. Buridan wins Landry's promise to go to 
Buridan's lodgings and to get a certain box under a flagstone and give it to King Louis $\mathrm{X}$ if Buridan is not on hand to claim it the next day. Marguerite comes to the Châtelet to gloat over her prisoner. Buridan reveals himself to her as Lyonnet de Bournonville, her former page and lover in Burgundy. They had had two children. Before the twins were born, Marguerite's father, Duke Robert, had discovered her condition and was about to send her to a nunnery, when he was murdered, at Marguerite's suggestion, by Buridan. She had given the children to Orsini with orders to kill them; instead, he had given them to Landry. Marguerite promises to have Enquerrand de Marigny executed and to make Buridan Prime Minister in his place.

Act IV. Buridan. - Tableau VII. Buridan, as Prime Minister, has ridden at the King's left on his triumphal entry into Paris. Gaultier has received orders to take command of the army in Champagne. Marigny has been executed.

Buridan has a rendez-vous with Marguerite for the evening at the Tour de Nesle. She will there receive her incriminating letters to him, and his love. Thinking she has him trapped, she gives Orsini orders for one last murder. Then she will tear down the tower and erect in its place a convent where prayers will be said for the souls of herself and Orsini.

Buridan gives Gaultier the key to the Tour de Nesle and turns the rendez-vous over to him, after telling him that he, Buridan, was Marguerite's accepted lover, showing him her letters and telling him it was she who murdered Philippe. Buridan has given orders under the King's seal for the arrest of all persons found in the Tour of Nesle. 
Act V. Gaultier d'Aulnay. - Tableau VIII. In a conversation with Landry, Buridan is told that his children had been abandoned, marked with a cross on the left arm. Buridan knows that both Philippe and Gaultier bear such marks. Realizing the fate awaiting Gaultier he hastens by boat to the Tour de Nesle, so as to anticipate the arrival of Gaultier who has gone on foot.

Tableau IX. The Tour de Nesle. Buridan enters the tower through a window and reveals to Mar: guerite the identity of Philippe and Gaultier. She swears that Gaultier has never been her lover and prays God for mercy. A cry of anguish is heard; it is the death-agony of Gaultier, murdered by Orsini; the door is locked. When the door, which had been locked, is opened, Gaultier staggers in with gaping wounds in time to hear Marguerite exclaim: "Malheureux, malheureux, je suis ta mère." His reply is "Ma mère? Eh bien, ma mère, soyez maudite!" He then falls at her feet. The High Sheriff enters and arrests all present. His comment is: "Ici il n'y a ni reine ni premier ministre; il y a un cadavre, deux assassins, et l'ordre signé de la main du roi d'arrèter cette nuit, quels qu'ils soient, cux que je trouverai dans la Tour de Nesle."

El paje and La Tour de Nesle have this in common, that they are representative of the Romantic melodrama in its extreme form. There is no development of characters in either play, but merely a series of breathless incidents. The interest depends solely upon the plot, the action of the plays, which certainly do not appeal to the spectator's intelligence, nor indeed to his emotions, but rather to his nerves. In 
both, a predilection for the terrible is conspicuous. Parricide and incest, assassination and adultery, are the commonplaces of such works. The individuality of the protagonists is carried to such an extent that they seem quite devoid of any sort of moral sense. Marguerite and Buridan, who have been ardent lovers, cheerfully plan each other's murder; Ferrando has but slight hesitancy in murdering Don Martin at Doña Blanca's request, and she has but few qualms at causing the murder so that she may more easily flee with her lover Rodrigo.

Moreover certain situations in the two plays are more than superficially similar. In each case the hero and heroine had been in illicit relations from which children resulted; in each case the heroine had later married a man of high rank from whom her past must by all means be concealed. In both plays the lover returns, and the rest of the action after his return hinges on his relations with his former mistress, the heroine of the play. In both plays the hero commits murder to further the designs of the heroine. In $\mathrm{El}$ paje, Ferrando falls in love with Blanca, who is later discovered to be his mother and who is the cause of his death. In La Tour de Nesle, both Gaultier and Philippe fall in love with their mother, Marguerite; her identity is not discovered until after she has caused the death of both of them. These sudden discoveries of kinship were favorite devices of the Romanticists, and we have already seen the same thing in Martínez de la Ro- 
sa's La conjuración de Venecia, in Pacheco's Alfredo, and in Garcia Gutiérrez's $\boldsymbol{E}$ l trovador.

Certain corresponding scenes of the two plays are similar even in their wording. Compare for example El paje, Act III, sc. 3 with La Tour de Nesle, Sixième Tableau, sc. 5. In the former play Rodrigo has discovered Nuño, to whom he had entrusted his infant son fifteen years before; in the latter, Buridan has found Orsini, to whom his two sons had been given.

\section{El paje}

Nwต̃o: El niño me dió Hastima, porque temblaba de frí y era bermoso como un sol. Le robije con mi gabin, y le llevé a una buena duerna para que le criase... ast pasaron dos años.

Rodrigo: ¿Y qué hiciste del niño al cabo de ese tiempo?

Nuño: El dinero se habia agotado; yo no podia daric de comer, y le abandoné a su suerte.

Rodrigo: Nuño, es preciso que indagues su paradero, te volverds conmigo a Sevilla, y yo te prometo darte cuanto pueda lisonjear tu ambición. Yo soy rico... i oh! búsca. me a mi bijo, y cuando vuelvas con tl, te colmaré de oro.

\section{La Tour de Nesle}

Orsini: Ahl Pardon, monseigneur, pardon de se les avoir pas fait mourit, comme on me l'avait ordonné. . Pardon si je n'en ai pas eu le courage; cétajent deux fils si faibles et si beaux!.. malheureux?

Buridan: Qu'en as-tu fait, Orsini: Je les ai donnes, pour les exposer, a un de mes hommes...

Buridan: C'est bien, Orsini... Oh! tu auras de lor ce que pesaient ces enfants: deux garsons, n'est ce pas? 0 mes enfants! mes entants!

The murder of Blanca's husband Martin corresponds closely to the killing of Marguerite's 
father. In La Tour de Nesle (Sixième Tableau, sc. 5) Buridan narrates how Marguerite had urged him to the deed:

Elle (Marguerite) tenait un poignard comme tu en tiens un, la jeune Marguerite, et elle disait "Lyonnet, Lyonnet, si, d'ici à demain, mourait mon père, il n'y aurait plus de couvent, il n'y aurait plus de séparation, il n'y aurait que de l'amour." Je ne sais comment cela se fit, mais le poignard passa de ses mains dans celles de Lyonnet de Bournonville; un bras le prit, le conduisit dans l'ombre, le guida comme à travers les détours de l'enfer, souleva un rideau, et le page armé et le duc endormi se trouvèrent en face l'un de l'autre. C'était une noble tête de vieillard, calme et belle, que l'assassin a revue bien des fois dans ses rêves; car il l'assassina, l'infâme!

In $E l$ paje, the murder of Martin is thus accomplished (Act III, sc. 8):

Blanca: ¿Lo escuchas? Te adoro

$\mathrm{Y}$ me separan de ti.

¿Por qué no acalla la muerte

Ese grito aterrador?

Ferrando: ¡Tú me amas!

Blanca:

¿Tienes valor?

Está en tu mano mi suerte.

Ferrando: Vida y alma tuyas son.

Blanca: $\quad$ No es tu vida lo que quiero...

¿Qué digo? Clava ese acero,

(Sacando el puñal del paje y poniéndolo en su mano.)

Clávalo en mi corazón.

Ferrando: ¡Tú morir!

Blanca: $\quad\lceil$ No, no, que es él! 
|fl morir debe, inhumano!

E. acero está en tu mano,

$Y$ en ese lecho...

Ferrando hesitates, but at last exclaims:

Perdóname tủ, Señor;

Que el ángel malo ha vencido.

and murders Martin.

The most important ròle in these two plays, as in so many Romantic dramas, belongs to the Goddess of Chance. It is more than a little strange that Ferrando, a nameless youth, should happen to become the page of his own mother, that he should happen to fall in love with her, that Rodrigo should happen to find an obscure boatman who had by chance returned to Seville only the day before, that Ferrando should take poison before rather than after telling Blanca that Rodrigo was his father. Any break in this line of fortuitous circumstances would have spoiled the whole plot. In La Tour de Nesle we have much the same thing. Suppose, for example, that Marguerite had not happened to write, sign and send to Buridan, as no clever woman would have done, a letter revealing her guilt in having her father murdered, the intrigue would become null and void. It may be said in Garcia Gutiérrez's favor that in his later works, and notably in Juan Lorenzo, the long arm of coincidence is by no means subjected to such violent wrenchings. El paje was written when the author was still in his early 
twenties, and it is an example of his most subservient adherence to Dumaesque methods.

In the same year (1837) García Gutiérrez wrote a drama entitled Magdalena, which differs considerably from his preceding works. In the first place, the action is supposed to be contemporary. In the second place, the play is not a Romantic drama but a drame bourgeois. It was considered immoral by the Junta de Iectura and was never played. ${ }^{36}$ The story is that of the faithless lover who repents just too late. Magdalena has been the mistress of Carlos, to whom she bears a son. Carlos tires of Magdalena and marries a marchioness, but on the morning of his wedding he happens to meet Magdalena, and the next day has a long talk with her. When he leaves her room, he is accosted by Magdalena's brother, who challenges him to a duel and kills him. Magdalena thereupon finds Carlos' will, leaving all his possessions to her and to their infant daughter.

Magdalena lacks the illusion of times past, the splendor of the feudal age, and there is no glamour thrown around the characters to make them interesting. The play is much weaker than $\mathrm{El}$ trovador - not nearly so vigorous, colorful and spontaneous. We may remark in passing that it must have been a strange censorship which suppressed

se Blanco García, op. cit., vol. i, p. 224. 
Magdalena and allowed La Tour de Nesle to be presented.

The play produced in 1837 under the title of El sitio de Bilboo, which is ascribed by Hartzen.

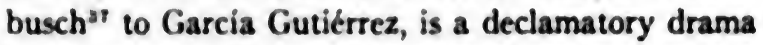
in two acts, in verse and prose, and cannot properly be classified as Romantic. It is an effort to utilize the Carlist war as a subject for drama and deals with the siege of Bilbao in 1836. The whole play is a glorification of Espartero.

La pandilla, o la elección de un diputado is said on the title-page to be a translation from Scribe, but the Spanish title hardly gives an immediate clue to the French one. The play in question is the one which Scribe entitled La camaraderie, ou la courte-ichelle, and which was presented in Paris in January, 1837, and had its Spanish presentation later in the same year. It is in five acts and in prose. It is quite typical of Scribe, for it contains a complicated plot, an abundance of cleverly manipulated situations and a series of hastily sketched characters. The play contains one passage which is of especial interest because it shows Scribe's attitude toward certain phases of the Romantic movement:

Oscar: Tu ne sais pas?.. J'ai fait un livre de poésies.

Edmond: Toi!

Oscar: Comme tout le monde!... Cela m'est

i Obrea eacogidas de Don Antonio Garela Gutibrres, pra face. D. xxili. 
venu un matin en déjeunant. Le Catafalque, ou poésies funéraires. d'Oscar Rigaut.

Edmond: Toi?... un gros garçon réjoui!

Oscar: Oui, je me suis mis dans le funéraire,... il n'y avait que cette partie-là, tout le reste étant pris par nos amis; des beaux... des gants jaunes de la littérature, génies créateurs ayant tout inventé; et ça aurait fait double emploi si nous avions tous créé le même genre. Aussi je leur ai laissé le vapoureux, le moyen-âge, le pittoresque; et j'ai inventé le funèbre, le cadavéreux, et j'y fais fureur.

It must have seemed a little disconcerting to García Gutiérrez that he should be translating for presentation on the Madrid stage this brief satire of the sort of work he was producing; for "le moyenâge" and "le pittoresque" are much in evidence in his plays. His very next play, El rey monje (1837), has its scene laid in Aragon in the twelth century. It is a Romantic historical drama in five acts and in verse, and contains some of its author's best poetry.

The hero of the play is the Monk King Ramiro, who actually reigned in Aragon from 1134 to $1137 .^{38}$ The veritable history of the period, however, is not followed, historical events being bent to suit the exigencies of the drama.

Ramiro greatly regrets that he is destined to be a monk, for he is in love with Isabel, the daughter of Don Ferriz Maza de Lizana. While visiting her in her apartments, he is discovered by her father

$\because$ Cf. M. A. S. Hume, The Spanish People, New York, 1909, p. 186. 
and flees. Don Ferriz pretends that his daughter is dead.

Ramiro becomes Archbishop of Roda, but on the death of his brother Alfonso of Aragon he accepts the throne. Later he discovers a conspiracy against him headed by Don Ferriz. The conspirators are all executed. Don Ferriz is beheaded just as Isabel arrives upon the scene to plead for his life. For a brief instant Don Ramiro hears her voice and then goes back to his royal duties.

The last act shows Ramiro in his old age; he has abandoned all worldly ambitions and cares, and has entered a monastery. To his confessional there comes a woman in black; from her story he recognizes her as Isabel. He tells her that his acts put an impassable barrier between them, and that they must forget the loves of their youth. Their conversation is interrupted by the entrance of Isabel's brother Alfonso, who has for years been seeking to wreak vengeance on Ramiro. Now, however, he is too late, for Ramiro sinks and dies as he arrives.

This play is typically Romantic in its background, its atmosphere and its style, but Ramiro is by no means preeminently the Romantic hero; he is not, like Don Alvaro or Hernani, ready to brave all dangers and to give up all else for his love. Moreover, the whole play is rather a series of episodes in the career of the principal character than a dramatic treatment of any one of them. It gives the impression of being rather loosely put together. The play proceeds not toward a dramatic climax or solution but comes merely to a close. Such was not the method of Hugo and Dumas. When they wrote 
historical plays, they chose some distinctive crisis in the life of the historic personage or some one startling event of his time. In Hugo's Marie Tudor, for instance, the interest of the play depends upon the love affairs of Gilbert and Lady Jane Grey, and upon the infatuation of Queen Mary for Fabiani. No attempt is made to treat the whole of Mary Tudor's career. The play is brought to a satisfactory dénoûment with the execution of Fabiani and the rescue of Gilbert. In Dumas' Catherine Howard the execution of the heroine by her lover Ethelwood furnishes a dramatic solution for a complete drama. In El rey monje Ramiro simply falls a victim to some mysterious illness at the end of the fifth act - and the play is over.

The verse of $F l$ rey monje reaches and maintains throughout a high level of excellence. Piñeyro says of it: "Es el cenit de su carrera de puro y elegante escritor;... nunca superó la fluidez y espontaneidad de forma, que en los dramas de este periodo es un encanto perdurable." ${ }^{39}$

Our author's plays of the next four years mark no advance in his power and no change in his method. They continue to abound in melodramatic situations, and the interest aroused comes from the events depicted rather than from any analysis of motives or careful delineation of character.

Simón Bocanegra, first represented at the Teatro

\& Piñeyro, op. cit., p. 104. 
de la Cruz on January 17, 1843, was Garcia Gutiérrez's next great success. It is in four acts, preceded by a prologue, and is written entirely in verse. The action of the prologue begins at Genoa in the year 1338; that of the play proper in the same city in 1362. The prologue really contains sufficient material for a complete drama in itself, while the plot of the play itselt is so complicated that it is at times difficult to follow. In the operatic form given to it by Verdi, Simone Boccanegra has not been nearly so successful as $\|$ Trovatore.

In the prologue we learn that Simon Bocanegra, a corsair, has just returned from three years' wanderings at sea. A movement is on foot to proclaim Simón "Dux" of Genoa. Simón himself is haunted by the image of Mariana, a girl of the nobility whom he had seduced years before and whom he still ardently loves. He goes to Jacobo Fiesco, the father of Mariana, and begs to be allowed to marry her. Fiesco asks him what has become of the child Mariana bore him; Simón confesses his ignorance. Entering Fiesco's house in an attempt to see Mariana, he finds her on her bier. As Simón leaves the house, he hears the people proclaiming him Dux of Genoa.

Act I. Gabriel Adorno is in love with Susana. Countess of Grimaldi, and she with him. Susana is the ward of a man known as Andrea, who is really Jacobo Fiesco in disguise. While Gabriel and Susana are conversing, a masked man approaches and informs them that the Dux of Genoa, Simón Bocanegra, is coming to Susana's house that day. Upon being questioned by Gabriel, Susana admits that the 
Dux has exhibited rather too much interest in her, but they agree that it will be best for her to see him.

Simón has shown himself to be a harsh tyrant in the twenty-four years of his rule over Genoa, and Gabriel's father had been one of his victims. Gabriel and Fiesco are forming a conspiracy to overthrow him. Fiesco informs Gabriel that his beloved Susana is in reality not the Countess Grimaldi but a foundling. Gabriel affirms that he loves her for herself alone, and Fiesco promises her to him if the conspiracy is successful.

Bocanegra comes to see Susana and puts into her hands a pardon for her supposed brothers the Grimaldis, exiled for political crimes. On his visit to Susana Bocanegra is accompanied by Paolo, who also is in love with Susana, and when Bocanegra leaves the room for a few moments Paolo makes off with her. Gabriel accuses Bocanegra of the abduction, but the crime is Paolo's own, and Bocanegra threatens him with torture unless he reveals Susana's whereabouts.

Act II. Susana is entrusted by Paolo to $\mathrm{Bu}$ chetto; Simón is brought to Buchetto's house by Paolo. Susana tells the Dux that she can remember the time when she was not a member of the Grimaldi household and when those around her called her Maria. Simón tells her the story of the prologue, and recognizes her as his own daughter. She expresses her affection for him, but agrees that her identity be kept secret. She also promises to come to Simón's palace.

Gabriel and Fiesco come to confer with Buchetto - who has joined the conspiracy against Simón and finds Susana there. Gabriel is in despair when, without giving any reason other than the Dux's 
command, she announces her intention of going to Simón's palace.

Act III. Paolo presses his suit with Susana and urges Bocanegra to accord to him her hand. Upon being refused he decides to overthrow Simón and offers Gabriel and Fiesco an opportunity to kill the Dux. Fiesco refuses to use ignoble means, but $\mathbf{G a}$ briel consents to commit the murder. In the palace Gabriel sees Susana and urges her to flee with him. She will not, and refuses to explain her relations with Simón. The latter then enters, and Susana hides Gabriel on the balcony. Simón falls asleep in his chair, and Gabriel is about to stab him when Susana stays his hand. Simón recognizes Gabriel; Susana had already informed her father of her love for the young man. Bocanegra suspects Susana of complicity in this attempt to murder him and in his lament refers to the fact that she is his daughter. Gabriel exonerates his beloved, and promises to defend Simon against the conspirators, who have now succeeded in arousing the populace and who are clamoring outside the palace. Simón promises Gabriel the hand of his daughter.

Act IV. Gabriel quiets the people, but Paolo, by dwelling on Mariana's shame, has roused Fiesco to a point of frenzy. He agrees to aid in poisoning Simón. They drug the cup in which Simón is to drink happiness to Gabriel. Fiesco meets Simón and is recognized by him as the father of Mariana. Begging Fiesco's forgivenes, he receives pardon just as the poison begins to take effect upon him. With his last breath he blesses Gabriel and Susana, and proclaims Gabriel Dux of Genoa.

The situations of the play are ingeniously contrived and effectively written. The characters are much 
more clearly outlined than in the plays before this date. Bocanegra, for example, is a distinct individual and not a mere personification of an abstract quality; his harshness is softened by an enduring love for Mariana and for his daughter Susana. Though he has been a severe ruler, he is capable of magnanimity, as evidenced by his forgiveness of Gabriel. He is a combination of good and bad elements, a real person, and not a dramatic puppet such as the incarnate ambition which stalks through the scenes of La Tour de Nesle under the name of Buridan. The character of Susana is even more delicately portrayed. She is tender and loving toward her father Simón and her lover Gabriel; resolute in dealing with her affairs (Act I, sc. 4), prudent in keeping her father's secrets (Act III, sc. 6), and always dignified and reserved. She is a more artistic creation than Leonor of El trovador. She and Bernarda of Juan Lorenzo stand preeminent among the personages of Garcia Gutiérrez's stage.

None of the dramas following Simón Bocanegra attains that play's standard of excellence until Venganza Catalana (1864). These twenty-one years saw only nine original plays which the author describes as "dramas." He began to write comedies and zarzuelas, which brought him more financial gain if less literary glory. During this time he produced no less than twelve zarzuelas, in addition to eight original comedies and five translations. The dramas 
show no change in method and no improvement in style. The comedies are weak in plot and none of them approaches the standard of his better dramas. Very early, with the writing of El trovador, he discovered his most successful style and method. It is interesting to note that the best of the zarzuelas, Ed grumete, was the first, which appeared in 1853.

Venganza catalana marks a return to the pattern of El trovador and Simón Bocanegra and, like them, it met with considerable success. The play is in four acts, entirely in verse, and the action is set at Adrianople and Apros in the year 1304. A note by the author at the end of the play mentions as historical authorities the chronicles of Ramón Mun. taner and Francisco de Moncada (Muntaner's Chronica, o descripcio dels fets et hazanyes del Inclyt Rey don Jaume, and Moncada's Expedición de los calalanes y aragoneses contra turcos y griegos).

Maria, princess of Bulgaria, cousin of Miguel Pa. leólogo, Emperor of Byzantium, is the wife of Roger de Flor. Roger is the leader of the Catalonians and Aragonese, who have just lent great aid to Miguel. Gircón, the leader of Miguel's allies, the Alanos, has a son Alejo and two daughters, Irene and Margarita. Years before, Alejo and Maria had been lovers and had sworn eternal faith to each other, but time and circumstances had driven them apart. Irene has been constantly in love with Roger. Margarita had been seduced by a man whose name she died without confessing, and Alejo has been endeavoring for six years to discover his daughter's 
betrayer. Gircón informs Alejo, now serving under Roger, that he has at last unearthed him.

Roger reveals to Maria and Alejo the fact that he had loved Margarita and had been married to her; she had committed suicide because, in his absence, she believed herself duped. Alejo rejoices, and promises Maria to cherish Roger for her sake.

Gircón tells Alejo that Roger caused his sister's dishonor and calls on him for vengeance. Alejo, without revealing his reasons, refuses to intervene. Miguel grows suspicious of Roger and his turbulent soldiers, and jealous of their power. He invites Roger to a banquet, at which Gircón assassinates him.

In a battle between the followers of Roger, now led by Berenguer, and those of Miguel, the Catalonians and Aragonese take dire vengeance on the Greeks, so that Roger's "coffin may swim in blood." Maria reports the battle from the ramparts of Apros. Her concluding words are:

Vencido el Oriente, nombra
con miedo al aragonés.
Llorando queda, y mañana,
aun después de enjuto el llanto
recordará con espanto
la venganza catalana.

This play recalls the freshness, vigor and spontaneity of García Gutiérrez's earlier work. Venganza catalana is a historical play rendered melodramatic by the addition of love episodes. Decidedly it is a Romantic work; its general lines are those of Gil y Zárate's Guzmán el Bueno, Hugo's Cromwell and Dumas' Catherine Howard. The interest is entirely in the story, which is composed of epi- 
sodes none too closely cemented. The author subjects himself to the same sort of difficulties as in $\boldsymbol{E}$ tro. vador, in which he combined the story of Azucena with the loves of Manrique and Leonor. In Vengansa cafalana he intermingles the vengeance of Gircon with the loves of Maria and Roger; further complicates the story with the Margarita episode and the love of Alejo for Maria; and connects all this with certain of the actual historical facts of the expedition of the Catalonians and Aragonese in Greece in 1304. Much of the popularity of the play must doubtless be credited (as in the case of Guzmdn el Bueno) to its patriotic note - a note which in this case is considerably out of harmony with the real facts of the case. Piñeyro calls attention to the words of Maria at the end of Act III, which, he says, are regularly greeted with a storm of applause by the audience." hear the tolling of the bell summoning Roger's soldiers to avenge his death, and ask what it means. Maria cries:

Pregunta necia!

¿Anuncia el fin de la Grecia!

¡Anuncia el rencor de España!

As a matter of fact Maria herself is a Byzantine Greek; Roger is a sort of free lance born in Italy of a German father; and the doings of a band of adventurous Catalonians and Aragonese soldiers,

-Op. cil.. pp. 112, 113. 
who in the early fourteenth century certainly had nothing of the modern idea of belonging to a united Spain, were hardly a legitimate cause for patriotic fervor in Madrid in 1864.

Venganza catalana is really the last Romantic play which Garcia Gutiérrez wrote, the last which connects him with the school of Hugo and Dumas. By his contemporaries it was not considered his best, though its success inspired his friends to publish "en obsequio del autor" 1 the collection of his Obras escogidas.

The compilers of the two-volume Autores dramaticos contemporáneos y joyas del teatro español (Madrid, 1881), under the general editorship of Cánovas del Castillo, selected to represent Garcia Gutiérrez his play Juan Lorenzo. This play was produced in 1865 , and is in four acts, all in verse. For the interest which it arouses it is less dependent upon the actual events related than any earlier play. It is at once a study of character and of the psychology of the popular uprising in Valencia in 1519. Juan Lorenzo, a man of noble soul and lofty purposes, leads the cause of the workingmen against the nobility; his less restrained followers get beyond his control and undertake to expel all the nobles from Valencia and confiscate their property. When Lorenzo protests against this persecution of the innocent along with the guilty, the men of the guilds

1. See Obras escogidas, preface, p. v. 
turn on him, accuse him of favoring the nobles and are clamoring for his death at the moment when, exhausted by his labors, chagrined at the ill success of his plans, aggrieved at the defection of his supposed friends and disheartened by his failure to accomplish his ideas, he dies of a broken heart. A love-motif lends interest to the plot. This is the first and last time that Garcia Gutierrez attempted a serious character drama; a continuation of such success might have added much to his fame.

Though Garcia Gutiérrez lived until 1884, he produced but few more plays, and these show marked evidences of decline. He wrote one more zarzuela, El capild́n negrero (1865), neither especially good nor especially bad - and one more historical play, Doña Urraca de Castilla, which manages to hold the reader's interest, while far below his earlier works in vigor and spontaneity. The other plays, Crisalida y mariposa (1872), Una criolla (1877), Un cuento de niños (1877), Un grano de arena (1880), are lifeless comedies, unworthy of the author of plays like El trovador and Simón Bocanegra. 



\section{CHAPTER V.}

\section{Concrusion.}

As may well be inferred from the preceding study, Garcia Gutierrez is one of the most important figures in the Spanish Romantic movement. He showed himself to be an able follower of Martínez de la Rosa, the Duke of Rivas, and Larra, who began their careers as Romantic dramatists only a very short time in advance of him. In poetic power he surpassed them. The plays which we have considered have revealed him as a skillful playwright, fertile in effective scenes and interesting plots. Under other influences he would doubtless have been able to moderate his tendency toward rather luridly melodramatic effects; in following this tendency he was but yielding to the literary fashion of his day. Various opinions may now be held with regard to the positive worth of that fashion and of the works which it produced, but we must not fail to judge Garcia Gutiérrez as a product of his own age and time. That he holds high rank among his contemporaries would hardly be disputed. The plots of his

\section{1}


plays are neither more nor less extravagant than those of his compeers. Such men as Hartzenbusch, Zorrilla, Isidoro Gil and Gil y Zárate wrote in just the same vein and followed the same models. El trovador seems almost restrained if compared with the Duke of Rivas' Don Alvaro or Zorrilla's Don Juan Tenorio, and is of quite the same character as Hartzenbusch's Los amantes de Teruel and Larra's Macias.

There is in many of the plays of Garcia Gutiérrez a lyric note which raises them from the level of melodrama to that of true poetry, and which greatly enhances their worth. He has the power to imbue with poetic beauty even the wildest Romantic extravagances. Is it not precisely this power which gives vitality to the dramas of Victor Hugo? Dumas entirely lacked it and his plays are therefore mere melodramas. And so Hernani lives on, while the plays of Dumas are nearly forgotten. It seems strange that Garcia Gutiérrez, possessed as he was of these lyric gifts, should have confined his ventures into the realm of lyric poetry proper to two small volumes. ${ }^{42}$ It may not be amiss to quote here a few illustrative passages from his dramas.

In $E l$ paje, not one of the author's best plays, there occur frequent outbursts of poetry worthy of a better environment. Let us read, for example, scene 8 of Act III. Doña Blanca surprises a look

12 Poesias, Madrid, 1840 : Luz y tinieblas, Madrid, 1842. 
of pain on the face of her page Ferrando and asks him its cause. He replies:

Ya no hay tormentos

Que no sufra mi pecho lastimado.

Pasó ya un tiempo en que la mente mia

De una beldad el hechicero halago

Con placer melancólico veia

Sin poderlo gozar; dichoso, empero,

Mi corazón ardiente palpitaba,

Porque un vago placer le alimentaba.

Cuántas veces entonces desvelado

$O$ en sueños apacibles, la veía,

Fantástica visión siempre a mi lado!

Y era ella misma, con su tez de nieve,

Con su sonrisa que de amor abrasa...

\section{Doña Blanca:}

¿Pronto fuiste infeliz!

\section{Ferrando:}

iTus ojos vierten

Llanto de compasión! Dichoso el hombre

Que del llanto de un ángel es la causa!

Dime, dime, señora: ¿̨tú de amores

Lloraste alguna vez? iAy! ¡Cuán terrible

Es amar en silencio, alimentarse

De lágrimas ardientes, ver la vida

Entre amargos ensueños deslizarse!

Again, the confessional scene of $\mathrm{El}$ rey monje (Act V, scene 4) is especially rich in passages of lyric beauty. Doña Isabel, loved long years before by Don Ramiro, now a monk, comes to his confessional and asks absolution because she has never 


\section{Conclasion}

been able to forget the love of her youth. They do not recognize each other until after the confession has been made.

\section{Don Ramiro:}

isí pasan por la vida

Una tras otra ilusión,

Que con belleza mentida

Despiertan del corazón

La esperanza adormecida!

$Y$ palpitando $\mathrm{y}$ ardiente

Se arrastra el afán del hombre

Tras de un fantasma luciente,

Tras de una cosa sin nombre,

Sueño tal vez de su mente.

El alma luego cansada,

Y en negras sombras perdida,

Vuelve a vagar en la nada,

Al mirar desvanecida

Su bella ilusión dorada;

Y esto, mujer, es vivir...

Esperar siempre o gemir

En sueño triste o risueño,

$\mathrm{Y}$ tener miedo al morir,

Aunque éste es el fin del sueño.

Doña Isabel:

Pequé; pero insensata amé el pecado;

Que no supe a su halago resistir,

$Y$ en ardiente placer embriagado

Sentí en mi pecho el corazón latir.

$Y$ día y noche en veladora cuita,

De santo altar arrodillada al pie,

A aquella Madre del Señor, bendita,

Por el ingrato sin cesar rogué. 
Yo, que he llenado de amargura y duelo De un triste padre la infeliz vejez, Yo, que le abri la tumba, isanto cielo! No maldije mi amor sola una vez.

Piedad de mi; que desdichada he sido, Merezca al menos mi dolor piedad; icaso mi destino se ha cumplido Y llega la terrible eternidad!

\section{Don Ramiro:}

Enlutada misteriosa,

Ya escuché tu confesión;

$Y$ cual tủ no hubiera cosa

Si eres, mujer, tan hermosa

Como lo es tu corazón.

¿De qué he de absolverte yo,

Blanca azucena inocente,

Porque infame pie te holló?

Alza del suelo la frente;

Que a Dios no ofendiste, no.

¿Tú viniste a derramar,

Angel puro, en el altar

Las lágrimas del pecado!

Yo también, mujer, he amado...

iEs.tan bermoso el amar!

¡Pecado! Dale otro nombre:

Esa es la vida, es la luz...

El mismo Dios, no te asombre,

Murió, por su amor al hombre,

Enclavado en una cruz.

The gift of writing vigorous as well as pathetic verse did not desert Garcia Gutiérrez as he grew older. The following lines from Venganza catalana (Act II, scene 4) also show, incidentally, the combi- 
nation of lines of different length, which he sometimes used to give variety to his verse:

Doloroso ejercicio

El de las armas es, $y$ todo gime,

Donde la impía guerra

Su dura planta imprime.

No hay mal que en pos no lleve,

$\mathrm{Ni}$ crimen, ni dolor, ni sacrificio;

Mas, ¿quién su furia a contener se atreve?

Lcyes dictad al huracán furioso

Cuando sus iras con fragor desata,

$Y$ enfrenad el impulso vigoroso

Del turbulento mar: sólo la mano

Del Hacedor, ante quien todo cede

Y el ímpetu le presta sobrehumano,

A sus preceptos sujetarlos puede.

It was this poetic power, it should be noted, that gave to García Gutiérrez a high place among the Romantic dramatists; without it he might well have remained a figure of secondary importance, like Isidoro Gil. We have endeavored to show in the foregoing chapters that the author of $E l$ trovador was a worthy follower of his immediate predecessors, without contributing anything entirely new and original to the principles of dramatic composition. He was content to follow the ideas prevalent at the time when he began his literary career. The general characteristics of the Romantic movement had become established before he exhibited them in his works. We have likewise endeavored to show that while the germs of Romanticism were in the Spanish 
theatre of the Siglo de Oro and had persisted be neath the surface even during the Eighteenth Century, it required an external influence coming from France to bring Spanish Romanticism to flower. The general characteristics of the work of Garcia Gutiérez were strikingly those of Hugo and Dumas.

The partisans of Romanticism in all lands endeavored to give expression not to widespread and generally accepted truths but to the individual, with his particular strivings and passions; they sought to describe the conflict of the individual with the laws and conventions of society. Hermani, Ruy Blas, Antony, Buridan, Don Alvaro, Macias and Diego Marsilla are all examples of this tendency; and Garcia Gutierrez formed the character of the troubadour Manrique in precisely the same mould as he did the characters of El paje, El rey monje, El tesorero del rey, Simón Bocanegra, Venganza catalana and of his other Romantic dramas.

As is the case with the French Romantic plays, the dramas of Garcia Gutiérrez appeal not to the reason but to the emotions. Manrique, for example, when he is confronted with an emergency does not stop like a Cornelian hero to consider just what his duty is; his feelings give him an unhesitating impulse to follow a certain course of action and without further ado be follows it. Not for a moment does he reason as to whether he ought to carry off Leonor from the convent; he loves her, desires her, and flees with her. The same impulsive course is followed by 
Antony. And so the spectator must follow not his reason but his emotions if he is to enjoy such plays. He must likewise be more concerned with the action per se than with any development of character. Though here it should be stated that García Gutiérrez was far less negligent in the creation of his characters than most of his contemporaries; the women characters especially are endowed with vitality enough to be real persons and are not mere personifications of ambition, hatred, passion or what not, like the characters of the theatre of the elder Dumas.

García Gutiérrez and his Spanish contemporaries also followed the principles of the French Romanticists in more external matters. They went back to the Middle Ages for their subjects and sought the same effects of color and picturesqueness. In the matter of verse and verse-forms the Spaniards were the more liberal; not content as were the French with merely giving more elasticity to one set form of verse, they employed a large variety of metres and even wrote some of their plays in alternating verse and prose. With regard to the number of acts, too, the Spaniards were more free, employing indifferently three, four or five. They frequently borrowed the French practice of giving a title to each of the acts. In these general respects Garcia Gutiérrez was quite as much indebted to the French as were his Spanish contemporaries. We have further endeavored to point out some of our author's par- 
ticular and, so to speak, private debts. In the case of $E$ trovedor we have seen that he was much beholden to Larra's Macios and that Macias in turn owed much to Dumas' Henri III ef sa cour. Since Garcia Gutiérrez translated for the Spanish stage Dumas' La tour de Nesle, Don Juan de Marana and Caligula, it seems all the more natural that the prolific French author's works should have been often present in the Spaniard's mind and should have furnished suggestions for his plays. His particular indebtedness for scenes or characters is, however, not nearly so important as his larger debt for the style and spirit of his plays, which are typically Romantic productions, exhibiting the typical characteristics of the Romantic plays shown in the French capital. Garcia Gutiérrez's distinctive merit lies in the fact that he was able to appropriate felicitously to himself the principles of the Romantic theatre, to produce on these principles dramas for which his contemporaries and later critics had a high regard,"s and to endow his works with poetic grace and beauty.

12 See for example Larra's review of $\mathbf{B l}$ trovador in Obrae de Larra, Caracas. 1839, vol. 11, D. Il: Plhiegro, op. cit.. DD. 95-116: and Blanco Garcia, op. cit., vol. 1. Dp. 217-ass. 



\section{BIBLIOGRAPHY.}

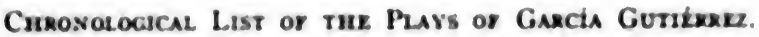

1. El vampiro. Comedia en un acto, escrita en francts por Scribe, y traducida al castellano por D. Antonio Garcia Gutiérrez. Madrid, 1839. (This play was first represented in 1834.)

2. Batilde, o la Amtrica del Norte en 1775. Drama histórico en cinco actos, escrito en francts por Mr. Scribe y traducido por D. Antonio Garda Gutierrez. Ma. drid, 1835.

3. El cudkero y la cómica. Comedia en dos actos, escrita en francts por Mr. Scribe, y traducida al castellano por D. A. G. G. Madrid, 1835.

4. El trovador. Drama caballeresco en cinco jornadas, en prosa y verso. Su autor, D. Antonio Garcia Gutierrez. Madrid, 1836.

5. Margarita de Borgoña. Drama en cinco actos y en prosa, del célebre Alejandro Dumas. Madrid, 1836.

6. El paje. Drama en cuatro jornadas, en prosa y verso. Su autor, D. Antonio Garela Gutiérrez. Madrid, 1837.

7. El sitio de Bilbao. Drama de circumstancias, en dos actos, en prosa y verso. Madrid, 1837.

8. Magdalena. Drama original en cinco actos, en verso y prosa. Su autor, D. Antonio Garcia Gutiérrez. Ma- drid, 1837.

9. La pandilla, o la elección de un diputado. Comedia en cinco actos $y$ en prosa, escrita en trancts por Mr. Scribe. Madrid, 1837.

10. El rey monje. Drama original en cinco actos y en verso. Su autor, D. Antonio Garcia Gutiérrez. Madrid, 1839. (First represented in 1837.)

11. El bastardo. Drama original, en cinco actos, por D. Antonio Garcia Guitérrez. Madrid, 1838. 
12. Juan Dandolo. Drama en tres actos y en verso, por D. José Zorrilla y D. Antonio García Gutiérrez. Madrid, 1839.

13. Samuel. Drama en cuatro actos, en prosa y verso, por D. Antonio García Gutiérrez. Madrid, 1839.

14. Caligula. Drama en cinco actos, precedido de un prólogo, por Alejandro Dumas. Traducido pot D. Antonio García Gutiérrez. Madrid, 1839.

15. Don Juan de Marana, o la caída de un ángel. Misterio en cinco actos, y éstos divididos en siete cuadros y dos intermedios. Escrito en francés por Mr. Alejandro Dumas. Madrid, 1839.

16. Estela, o el padre y la hija. Drama en dos actos, traducción de D. Antonio García Gutiérrez. Habana, 1839; Madrid, 1852.

17. Los desposorios de Inés. Drama en tres actos y en verso, por D. A. Garcia Gutiérrez. Madrid, 1840.

13. El encubierto de Valencia. Drama en cinco actos y en verso, por D. Antonio García Gutiérrez. Madrid, 1840.

19. El caballero de industria. Comedia original en tres actos y en verso, por D. Antonio García Gutiérrez. Madrid, 1841.

20. El caballero leal. Drama histórico original, en tres actos y en verso, por D. Antonio García Gutiérrez. Madrid, 1841.

21. Zaida. Drama original en cuatro actos y en verso, por D. Antonio García Gutiérrez. Madrid, 1841.

22. Juan de Suavia. Drama en cuatro actos y en prosa. Madrid, 1841. Arreglado del francés por los Sres. D. Antonio García Gutiérrez y D. Isidoro Gil.

23. El premio del vencedor. Drama en tres actos y en verso, por D. Antonio García Gutiérrez. Madrid, 1842.

24. Simón Bocanegra. Drama en cuatro actos, precedido de un prólogo, por D. Antonio García Gutiérrez. Madrid, 1843.

25. De un apuro, otro mayor. Comedia en dos actos, por D. Antonio García Gutiérrez. Madrid, 1843.

26. El hijo del emigrado. Drama en cuatro actos, escrito en francés por Mr. A. Bourgeois. Traducido libremente por D. A. G. Gutiérrez.) Madrid, no date. (It was first represented in 1843.)

27. La ópera y el sermón. Comedia en dos actos, escrita en francés por Mr. Laurencin. (Traducida libremen- 
te por D. A. G. Gutitsrez.) Madrid, no date. (It was first represented in 1843.)

23. El saldn invisible. Comedia en dos actos, escrita en francts por Mr. Melesville. (Traducida por D. A Garcia Gutiérrez. Madrid, 1844.

29. Las bodas de Doña Sancha. Drama original en tres actos y en verso. Su autor, D. Antonio Garcia Gutiérrez. Madrid, 1844.

30. Gabriel. Drama original en tres actos y en verso. por don Antonio Garda Gutierrez. Madrid, 1844.

31. Emperios de una vengansa. Drama original en ires actos y en verso. Su autor, D. Antonio Garcia Gutiérrez. Madrid, 1844.

32. La mwjer valerosa. Drama en cuatro actos y en verso. Su autor, D. Antonio Garcia Gutiérrez. Madrid, 1844.

33. Los alcaldes de Valladolid. Drama en tres actos y en verso, original de don Antonio Garcia Gutierrez. Mérida de Yucatán, 1844.

34. El secreto del ahorcado. Drama en cuatro actos, por D. Antonio Garcia Gutiérrez. Mérida de Yucatín, 1845.

35. La gracia de Dios. Comedia en cuatro actos, de Mr. Gustavo Lemoine, traducida el castellano por D. Antonio Garcia Gutiérrez. Habana, 1846.

36. Los hijos del tio Tronera (parodia del Trovador). Comedia en un acto $y$ en verso, por D. Antonio Garcia Gutiérrez. Habana, 1846.

37. El tejedor de Jdsiva. Drama en tres actos, original y en verso de los señores D. Antonio Garcia Gutiérrez y D. Eduardo Asquerino. Madrid, 1850.

38. El tesorero del rey. Drama en cuatro actos, original de D. Antonio Garcia Gutierrez y D. Eduardo Asquerino. Madrid, 1850.

30. A fectos de odio y amor. Comedia en tres actos y en verso, original de D. Antonio Garcia Gutierrez. Madrid, 1850.

40. Dos a dos. Comedia en un acto, por D. Antonio Garcia Gutiérrez. Censurada para el teatro de Tacón en 4 de Noviembre de 1851 .

41. El trovador. Drama en cinco jornadas y en verso, por D. Antonio G. Gutiérrez. Refundido para el teatro Español. Madrid, 1851.

42. Los millonarios. Comedia en tres actos, original de D. Antonio Garcia Gutiérrez. Madrid, 1851. 
43. La Baltasara. Drama en tres actos y en verso, por D. Miguel Agustín Príncipe, D. Antonio Gil y Zárate y don Antonio Garcia Gutiérrez. Madrid, 1852.

44. El grumete. Zarzuela en un acto, letra de D. Antonio Garcia Gutiérrez, música de D. Emilio Arrieta. Madrid, 1853.

45. La espada de Bernardo. Zarzuela en tres actos y en verso, letra de D. Antonio García Gutiérrez, música de D. Francisco Asenjo Barbieri. Madrid, 1853.

46. La caceria real. Zarzucla en tres actos, letra de D. Antonio Garcia Gutiérrez, música de D. Emilia Arrieta. Madrid, 1854.

47. Un dia de reinado. Zarzuela en tres actos, traducida y arreglada de una ópera cómica francesa de MM. Scribe at de Saint-Georges, por D. A. Garcia Gutiérrez y D. L. Olona. Madrid, 1854.

48. La bondad sin la experiencia. Comedia en tres actos por D. Antonio García Gutiérrez. Madrid, 1855.

49. Asón Visconti. Zarzuela en tres actos, letra de D. Antonio García Gutiérrez, música de D. Emilio Arrieta. Madrid, 1858.

50. Cegar para ver. Zarzuela en un acto, letra de D. Antonio García Gutiérrez, música de Salvador Ruiz. Madrid, 1859.

51. El robo de las sabinas. Zarzuela en dos actos, letra de Antonio García Gutiérrez, música de D. Francisco Asenjo Barbieri. Madrid, 1859.

52. Un duelo a muerte. Drama en tres actos y en verso, por D. Antonio García Gutiérrez. Madrid, 1860. (An adaptation of Lessing's Emilia Galotti.)

53. Llamada y tropa. Zarzucla en dos actos, letra de D. Antonio García Gutiérrez, música de D. Emilio Arrieta. Madrid, 1861.

54. Dos coronas. Zarzuela en tres actos y en verso, arreglada del francés, letra de D. Antonio García Gutiérrez, música de D. Emilio Arrieta. Madrid, 1861.

55. Galán de noche. Zarzuela en dos actos y en verso (traducción), letra de D. Antonio Garcia Gutiérrez, música de D. José Inzenga. Madrid, 1862.

56. La tabernera de Londres. Zarzuela original, en tres actos, letra de D. Antonio García Gutiérrez, música de D. Emilio Arrieta. Madrid, 1862.

57. La vuelta del corsario. (Segunda parte del Grumete). Zarzuela en un acto, letra de D. Antonio García tiérrez, música de D. Emilio Arrieta. Madrid, 1863. 
58. Eclipse purcial. Comedis en tres actos, por D. Anto. nio Garcla Gutitrrez. Madrid, 1863.

59. Las cañas se vwelven lanzas. Comedia en tres actos, por D. Antonio Carcla Gutitrtez. Madrid, 1801.

0. Vempansa catalona. Drama en cuatro actos, pot I). Antonio Garcla Gutierrez. Madrid, 1804.

o1. J wam Lorenso. Drama en cuatro actos, por D. Antonio Gareta Ciutierrez. Madrid, 1865.

02. BI capiedin neguero. Zarzucla en tres actos, letra de D. Antonio Carcia Gutitrrez, música de D. Emilio Arricta. Madrid, 1865.

67. Crisdlida y mariposa. Juguete cómico en dos actos. por D. Antonio Garcia Ciutierrez. Madrid, 1872.

o4. Dohia U'rraca de Castilla. Comertia en tres actos y en verso, original de D. Antonio Garcia Gutitrrez. Ma. drid, 1872.

o.5. Noblesa obliza. Comedia en tres actos y en verso, original de D. Antonio Garcia Gutiérrez. Madrid, $18 \% 2$.

66. Un cuento de miños. Comedia en dos actos y en verso, original de D. Antonio Garcia Gutiérrez. Madrid, $187 \%$.

67. Una criolla. Comedia en tres actos y en verso por I). Antonio Gareía Gutiérrez. Madrid, 1877.

as. Un gramo de arrna. Corisedia en tres actos y en verso, original de D. Antonio Carcia Gutiérez. Madrid, 1880.

(The above list is copied from the title-pages of the plays and from the list furnished by Hartzenbusch in Obras esco. gidas de Don Antonio Garcia Gutiérrez, Madrid, 1866, with the addition of those published after 1866.)

Non-Drasatic Works of García Grtitrezz

1. Un baile en casa de Abrantes. Madrid. 1834.

2. Poeslas. Madrid, 1840.

3. Lws y timieblas. Poesias sagradas y profanas. Madrid, 1842.

4. El dwende de Valledolid, tradición yucateca. Madrid, 1850.

5. Articles entitled EL Casador and $\boldsymbol{E}$ J Memorialista in Los españoles pintados por si mismos, Madrid, 1851.

- Discurso de recepción en la Real Academia Espanola. Madrid, 1862.

7. Al rey de España, Amadeo I. Oda. Madrid, I8it. 


\section{Bibliography}

The only collected edition of certain of Garcia Gutiérrez's works is the one already mentioned:

Obras escogidas de Don Antonio Garcia Gutiérrez. Edición hecha en obsequio del autor. Madrid, Rivadeneyra, 1866. (This collection was made by a committee, the chairman of which was Juan Eugenio Hartzenbusch. It contains the following plays: El trovador, El paje, El rey monje, Juan Dandolo, Samuel, El tesorero del rey, La espada de Bernardo, El grumete, La cacería real, La bondad sin la experiencia, Un duelo a muerte, La vuelta del corsario, Venganza catalana, Juan Lorenzo, El capitán negrero, Las cañas se vuelven lanzas.)

\section{Works Devoted Fxclusively to García Gutiérrez.}

Funes, Enrique. Garcia Gutiérrez: Estudio critico de su obra dramática. Cadiz and Madrid, 1900.

Regensburger, Karl. Uber den Trovador des García Gutiérrez. Berlin, 1911.

Works Containing Criticisar of Garcia Gutiérrez's Plays. Blanco García. La literatura española en el siglo XIX. 3 , 30 ?
vols. 3d edition, Madrid, 1910. Vol. III, chap. xii.

Hartzenbusch, J. E. Obras escogidas de Garcia Gutiérrez, already mentioned. Prólogo, pp. v-xxii.

Larra, J. M. de. Obras, 2 vols. Caracas, 1839. Vol. II, pp. 41-45. There is another edition entitled Obras completas de Figaro. Paris, 1848. 2 vols.

Novo y Colson, Pedro de. Autores dramáticos contemponineos y joyas del teatro español del siglo XIX. 2 vols. Madrid, 1881. Vol I, pp. 81-96, by Cayetano Rosell.

Piñeyro, Enrique. El romanticismo en España. Paris, 1904. Pp. 95-116.

The current manuals and histories of Spanish Literature, such as those by Fitzmaurice-Kelly, Butler-Clarke, Ernest Mérimée, Schack, Revilla, Salcedo i uiz and others devote very little space to García Gutiérrez sind add nothing to the information contained in the works $r$.abtioned above. 
Wonks Beskisf: os me Kostantic Dusse is Spass.

Azorin (Martinez Kuix, Joxk). Rivas y Larra: rasón sucial del romanticismo. Madrid, 1010.

Donoso Cortes Obras. Madrid, 1854. I vols. See in vol. II the article entitled El clasicismo y el romamticis. mo. which was firse published in El Correo Niacional in 1838.

Ferrer del Rio. Guleris de lo liseraturn espaniole. Madrid. 1846.

Hurne, Martin A. S. Modem Spain, Tis8-1898. New York. -1000 .

Hunear. Guillaume. I:influence de REipogne sur le thedire fruagais des XVIII et XIX sizdes. Paris, 1912.

Le Gentil. Georges. Le potte Bretion de los Herreros at la socisit espagnole de 1890 d 1800 . Paris, 1000.

Mentondez y Pelayo, M. Historia de las ideas estéticas en Esparia. O vols. Madrid, 1883-1891. 2d edition, vol. VI. Madrid, 1004: vol. VII, Madrid, 1907.

Mentndez y Pelayo, M. Estudios de critica literaria. 5 vols. Madrid, 1893-1908.

Mesonero Remanos, R. de. Memorias de wn setentón, noiural y vecino de Madrid. Madrid, 1880.

Mesonero Romanos, R. de. Obras. Madrid. 1881.

Molins, Marqués de. Bretón de los Herreros. Madrid, 1883.

Villergas, Jose. Juicio critico de los poetas espuñoles conlemporineos. Paris, 1854.

Yxart, Josk. El arte esctnico en Espania. 2 vols. Barcelona, $1894-1896$.

Zorrille. Jose. Recuerdos del tiempo viejo. Madrid, 1882.

Fixis 



\section{CON'TEN'TS}

Pase

Chapter I. Biographical Sketch. 0

Chajper 11. The Advent of the Romantic Itrama in Spain. $\quad: 3$

Chapter III. First Dranatic Altempls aud Hil Tro. vador … ....

Chapter IV. Romantic Plays Subsequent to El Trovador .......................................... 10.3

Chapter V. Condusion ................................. 1.31

Bibliography .................................................... $1+1$ 
0 



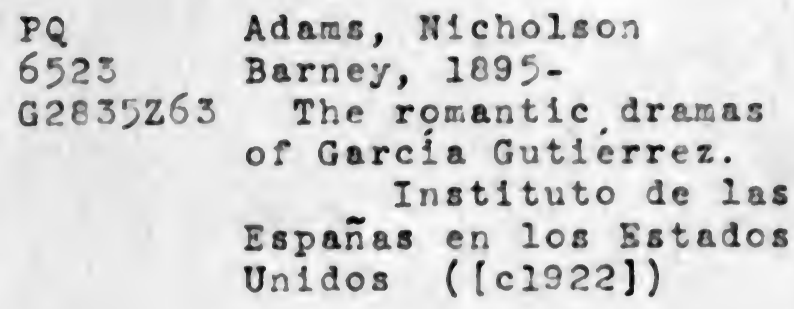

\section{PLEASE DO NOT REMOVE CARDS OR SUIPS FROM THIS POCKET}

\section{UNIVERSTTY OF TORONTO LIBRARY}


